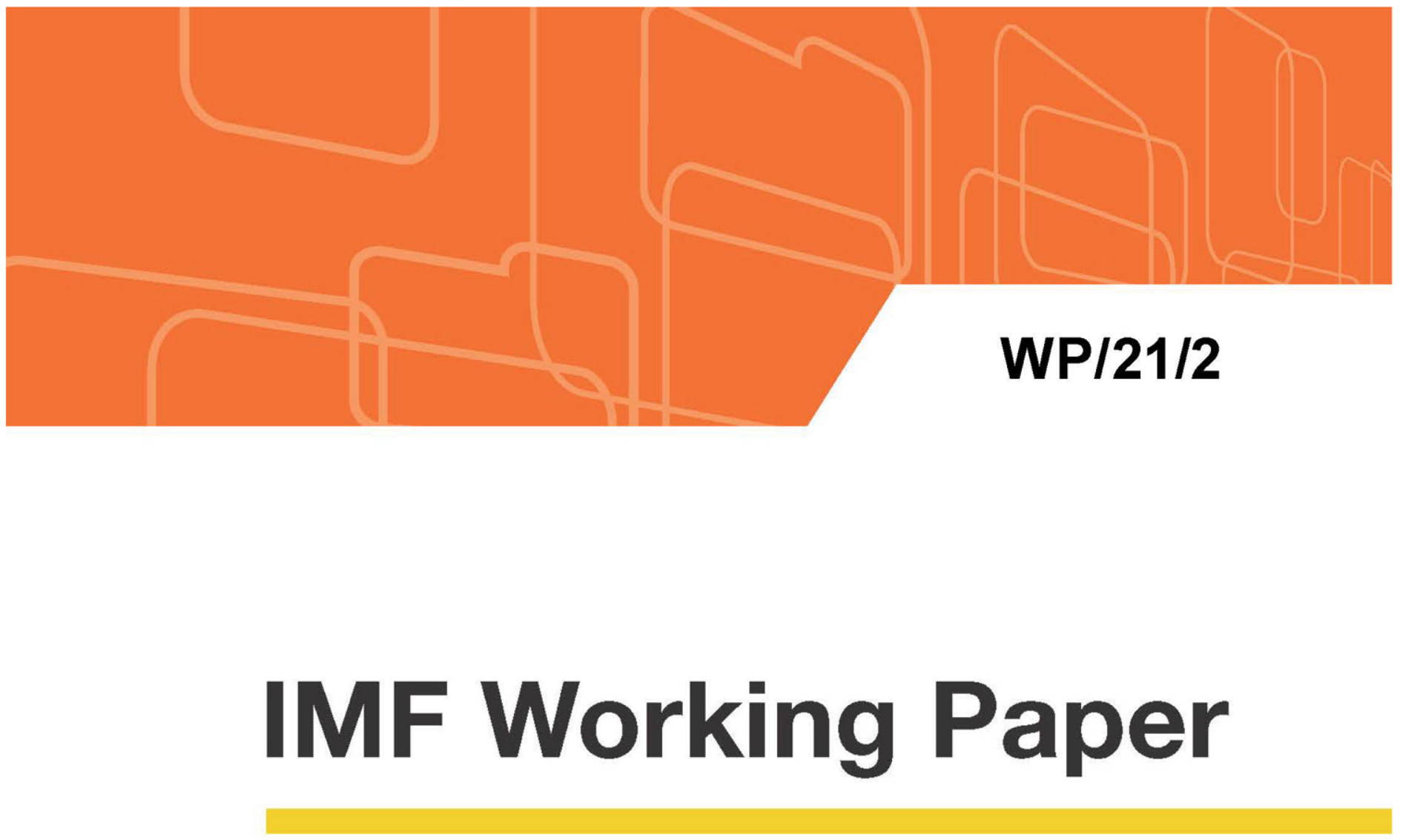

\title{
Dissecting Economic Growth in Uruguay
}

by Natasha Che

IMF Working Papers describe research in progress by the author(s) and are published to elicit comments and to encourage debate. The views expressed in IMF Working Papers are those of the author(s) and do not necessarily represent the views of the IMF, its Executive Board, or IMF management. 


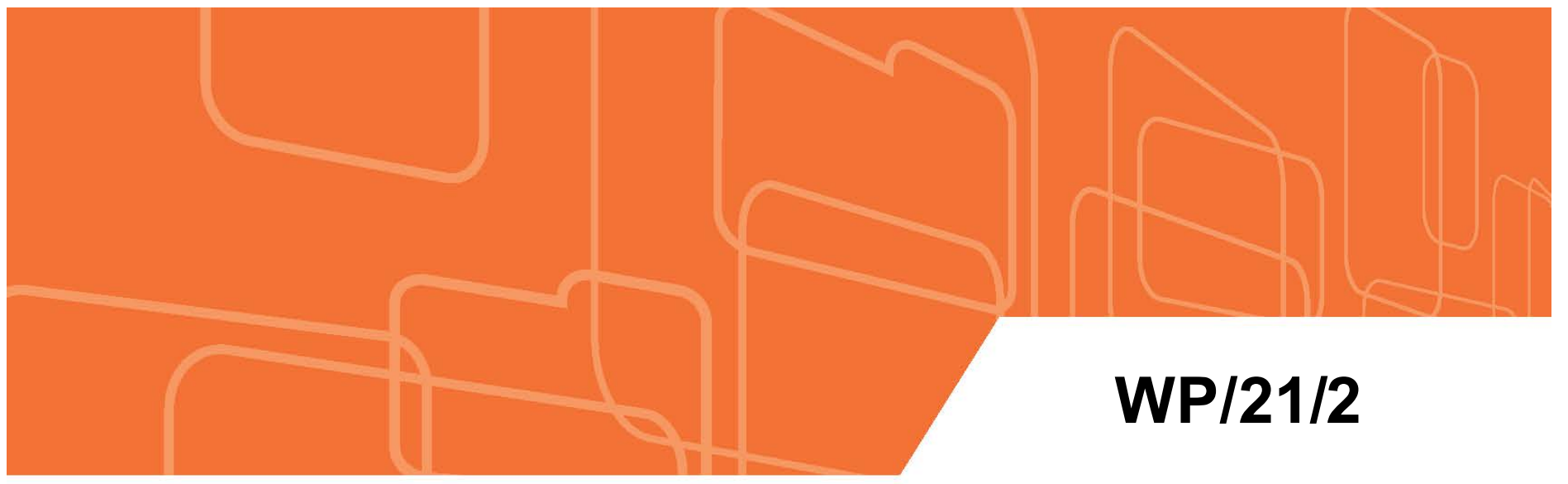

\section{Dissecting Economic Growth in Uruguay}

by Natasha Che

IMF Working Papers describe research in progress by the author(s) and are published to elicit comments and to encourage debate. The views expressed in IMF Working Papers are those of the author(s) and do not necessarily represent the views of the IMF, its Executive Board, or IMF management. 


\title{
IMF Working Paper
}

Western Hemisphere Department

\section{Dissecting Economic Growth in Uruguay}

Prepared by Natasha Che

Authorized for distribution by Patricia Alonso-Gamo

January 2021

\section{IMF Working Papers describe research in progress by the author(s) and are published to} elicit comments and to encourage debate. The views expressed in IMF Working Papers are those of the author(s) and do not necessarily represent the views of the IMF, its Executive Board, or IMF management.

\begin{abstract}
Uruguay experienced one of its biggest economic booms in history during 2004-2014. Since then, growth has come down significantly. The paper investigates the various causes of the boom and discusses the sustainability of these causes. It then compares Uruguay against high-growth countries that were once at a similar income level, across a broad set of structural indicators, to identify priority reform areas that could improve long-term growth prospect.
\end{abstract}

JEL Classification Numbers: O1, O2, O4, O5

Keywords: economic growth, Uruguay, commodity price boom, sustainable growth, economy of Uruguay

Author's E-Mail Address: nche@,imf.org 


\title{
Dissecting Economic Growth in Uruguay
}

\author{
Natasha Che*
}

January 4, 2021

\begin{abstract}
Uruguay experienced one of its biggest economic booms in history during 2004-2014. Since then, growth has come down significantly. The paper investigates the various causes of the boom and discusses the sustainability of these causes. It then compares Uruguay against high-growth countries that were once at a similar income level, across a broad set of structural indicators, to identify priority reform areas that could improve long-term growth prospect.
\end{abstract}

Keywords: economic growth, Uruguay, commodity price boom, sustainable growth, economy of Uruguay

JEL Codes: O1, O2, O4, O5

*I thank Pelin Berkman and the IMF's Uruguay country team for helpful discussions. The paper also benefited from conversations with colleagues at Banco Central del Uruguay and at various private sector institutions. I take sole responsibility for the views expressed in the paper. 


\section{Introduction}

Following a severe financial crisis in the late 1990s that had disrupted banking system, exchange rate and fiscal position, Uruguay enjoyed one of its most significant economic booms during the period of 2004-2014. Over this 10-year span, the annual growth in real GDP per capita averaged 4.9 percent, much higher than the 2.3 percent of Latin America and the Caribbean (LAC) average.
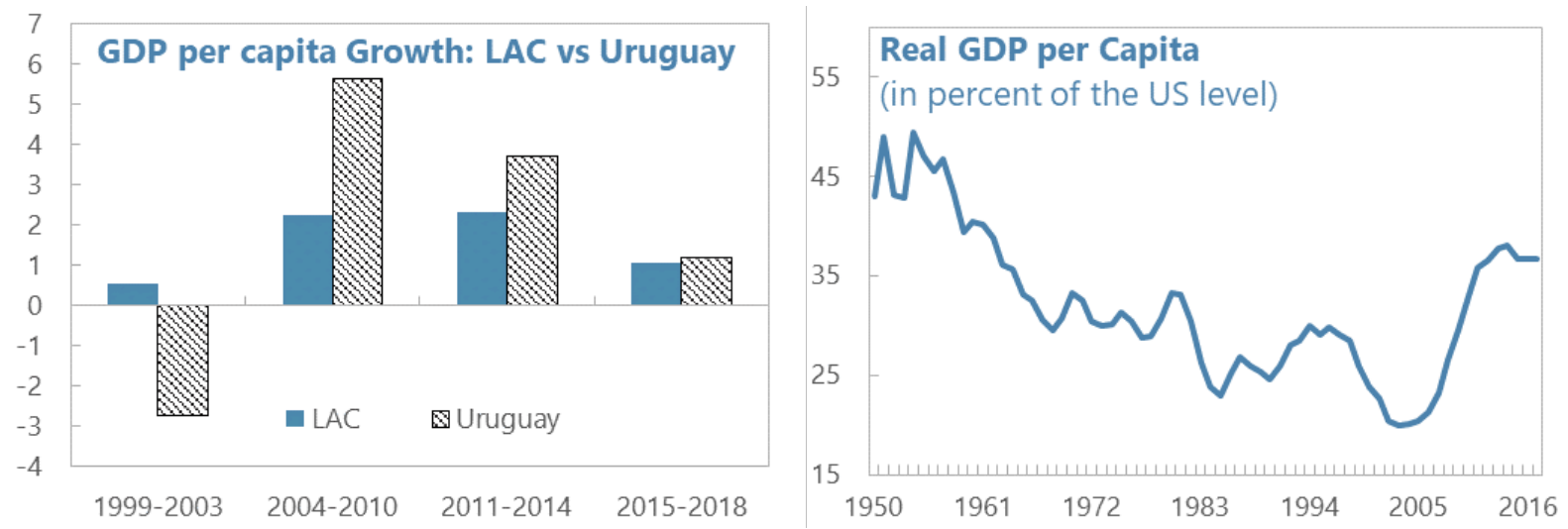

The significance of the boom can be seen by examining Uruguay's convergence record with advanced countries. Prior to the boom, for 50 years Uruguay's GDP per capita had been growing at an average annual rate of under 1 percent. Consequently, the GDP per capita relative to the US level had been on a consistent decline since the $1950 \mathrm{~s}$, until the trend was sharply reverted in 2004. In other words, the boom greatly facilitated Uruguay's income convergence with advanced economies.

Understanding the causes of this recent boom is valuable for designing a long-term growth strategy. Growth has slowed down significantly after 2014 - the real GDP growth averaged 1.6 percent from 2015 to 2018 . Why has growth dropped? Is the slowdown temporary, or is growth going back to its long-term, 1-percent trend after a brief spike? How to make growth more sustainable over the long run? To answer these questions, helpful insights can be gained by differentiating the short-term causes of the recent boom from the sustainable, longer-term causes, and studying the factors that can strengthen the latter. 
Identifying the structural impediments to growth will also inform a sustainable growth strategy. What structural reforms does Uruguay need to make growth more sustainable? International comparisons can provide a valuable perspective for answering this question. The paper compares the various structural factors of the Uruguay economy with those of a group of countries that were once at a similar income level and have since converged fast with advanced economies, as well as those of Uruguay's export competitors. The goal is to identify potential structural weaknesses where reforms may be necessary to improve the country's international competitiveness and growth potential.

The paper is structured as follows. Section 2 analyses the contributing factors to the latest boom. Section 3 evaluates their relative importance in the boom. Section 4 assesses the sustainability of the growth drivers. Section 5 compares Uruguay with the aforementioned peer groups and identifies the potential structural blockages for sustainable growth. Section 6 concludes.

\section{Drivers of the Recent Boom}

The surge in growth during 2004-2014 is due to a confluence of demand- and supply-side factors. These factors, which are explained in more details below, broadly include: the bounce-back effect from the previous crisis, a commodity price boom, increasing external demand, and the emergence of new export sectors.

\subsection{Recovery from the Crisis}

Uruguay suffered one of its worst crises in the late 1990s. The crisis was intimately related to the collapse of the Argentine economy at the time, and the banking and debt crises associated with it. Over the period of 1998-2003, Uruguay's GDP growth averaged -1.7 percent, the worst growth performance in Latin America over that period, except for Argentina and Venezuela. 


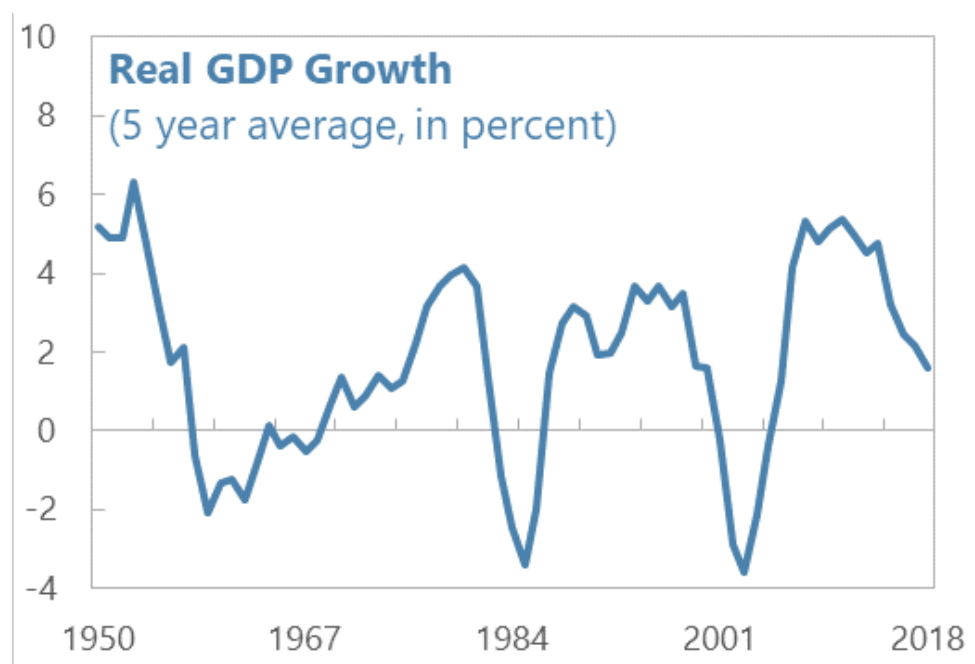

Uruguay's growth has been mean-reverting. An augmented Dickey-Fuller test applied to the annual GDP growth series of Uruguay strongly rejects the null-i.e., the series contains a unit root-at 1 percent level. ${ }^{1}$ The stationarity of the growth series suggests that extraordinarily low values in the series tend to be followed by the opposite. The pattern can also be readily observed by visualizing the growth data in a chart. To put it in another way, higher growth tends to follow an abnormally low base. The recovery from the severe recession before 2004 thus partly explains the strong growth for at least the initial years of the boom period.

\subsection{Terms of Trade Shock and External Demand Boom}

\subsubsection{Commodity Price Boom}

The commodity price boom during the 2000s stimulated growth. Around 50 percent of Uruguayan exports are agricultural commodities and their derivatives. ${ }^{2}$ In addition to the income effects, the commodity price boom starting in the early 2000s facilitated the growth of value-added and investment of the agricultural sector.

The commodity price boom also had a large impact on Uruguay's export structure. Soybean production and exports rose from nearly negligible in the early 2000s to account for 15 percent of total exports in 2014. The rising demand from China over the period was

\footnotetext{
${ }^{1}$ See Annex 1 for the test result.

${ }^{2}$ The Banco Central del Uruguay aggregates the ISIC classification for exports, which consists of three broad categories: primary activities, manufacturing industries, and electricity, gas, and water. Products are classified as part of manufacturing as long as there is an element of post-primary value added.
} 
the main driver of the increase in soybean price. As the price boomed, exports to China also grew. By the end of the boom period, China had surpassed Brazil and Argentina to become the most important export destination of Uruguay, with soybeans accounting for over half of total exports to China. After 2014, however, soybean exports quickly declined as the price came down, which we'll discuss in section 4.
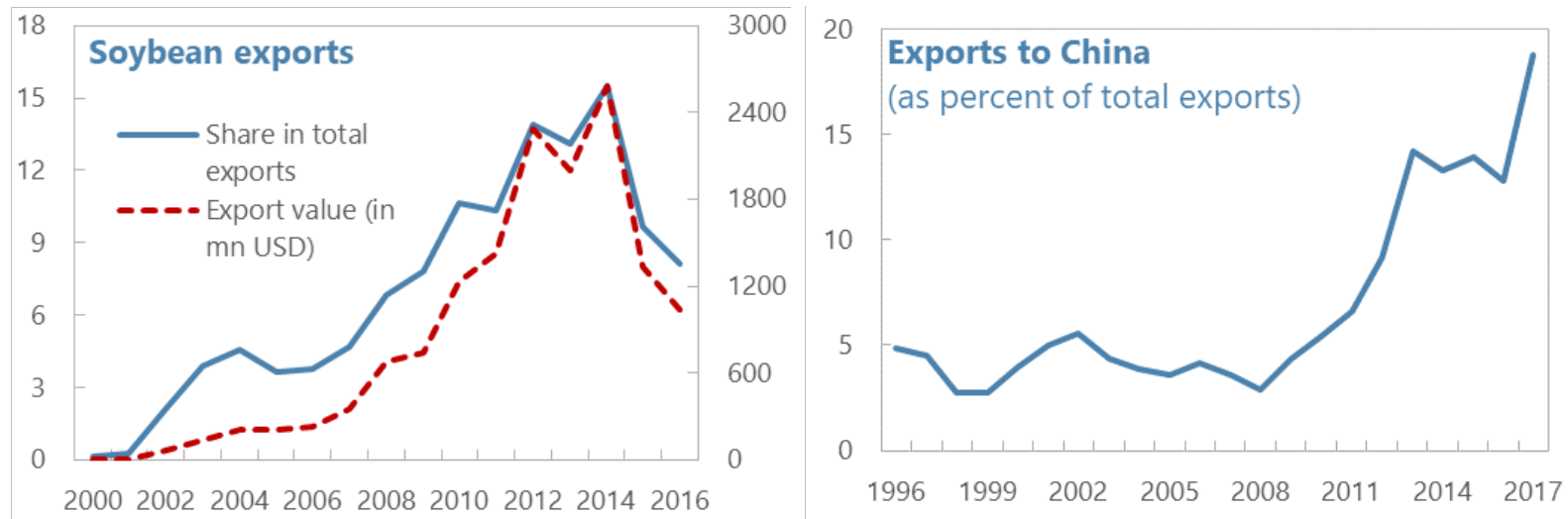

\subsubsection{Inflows from Argentina}

Historically the Uruguayan economy is intimately connected with that of Argentina. The crisis in the late 1990s was significantly associated with the currency and financial crises in Argentina. After the crisis, the financial linkages with Argentina have been reduced, with non-resident deposit declining from about 40 percent of total deposits in 2001 to less than 10 percent in 2018. On the real economy side, while goods exports to Argentina declined (from close to 15 percent of total goods exports in 2001 to less than 5 percent in 2018), the service exports to Argentina, tourism specifically, remains substantial. And as will be discussed in the next section, due to the close association between service exports and domestic nontradable sector, Argentinian tourism demand may have a higher influence on Uruguay's domestic price level, compared to the external demand for other tradable goods.

Increased inflows from Argentina during the boom boosted aggregate demand. Over the boom period, like many other Latin American countries, Argentina was a beneficiary of benign external conditions, including rising commodity prices and higher world demand. Higher 

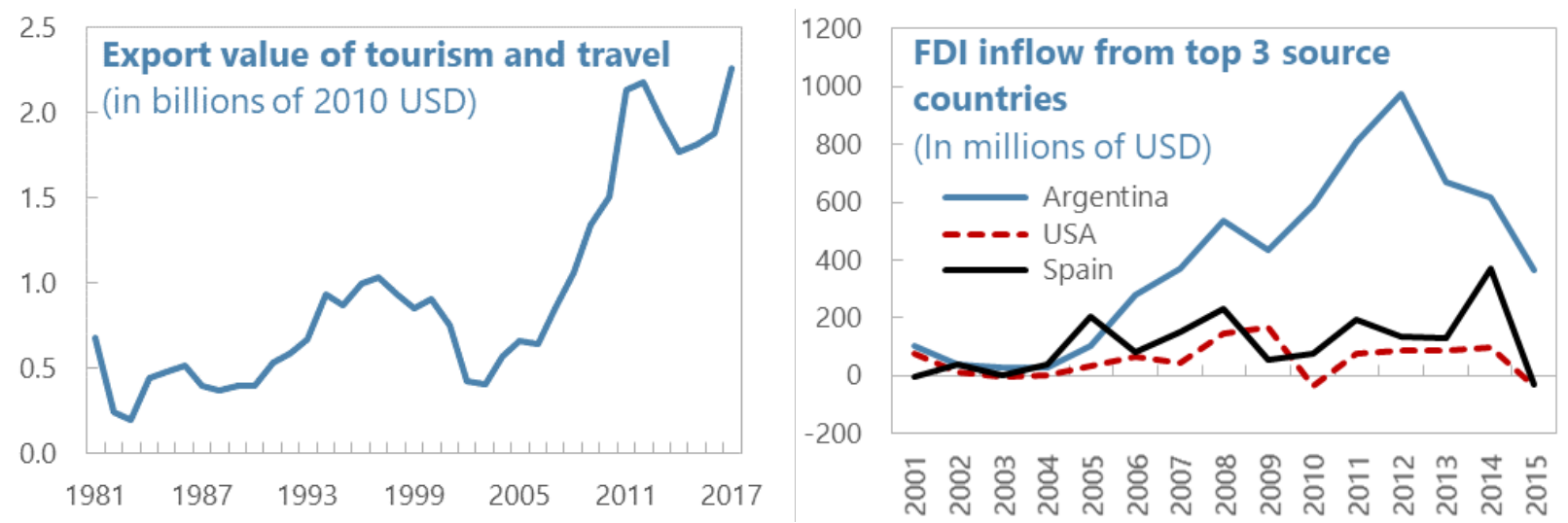

growth, combined with a policy environment that discouraged domestic investments, stimulated investment outflows from Argentina to Uruguay. During the commodity boom period, investment inflows from Argentina was significantly higher than before. From 2002 to 2012, annual foreign direct investment (FDI) from Argentina increased by 26 times. In addition, though Uruguay has increasingly diversified its destinations for goods exports throughout the 2000s, Argentina remains the largest client for service exports, notably travel and tourism, which constitutes over 15 percent of total exports. Tourism exports grew at an annual rate of 16 percent during the boom, much higher than the pre-boom period, largely aided by increasing demand from Argentina.

\subsubsection{Exchange Rate Appreciation}

The nominal and real exchange rates appreciated during the boom in line with regional trends. During the 2000s, due to the positive terms of trade movement and growing commodity demand, currencies of the region almost universally appreciated. Uruguay is no exception, with nominal exchange rate vs. USD appreciating over 20 percent from 2004 to 2014. Real GDP in PPP terms almost doubled over the boom period, compared to 68 percent increase without PPP adjustment.

The income effect from the nominal exchange rate appreciation helped boost domestic demand in the short term. As a small open economy, Uruguay relies on imports to fulfill a large share of its needs in both consumption and investment goods. Thus at least in the 
short run, the appreciation supported aggregate demand and growth, by boosting the de facto domestic purchasing power. ${ }^{3}$

\subsection{Sectoral Structural Change}

The 2000s saw significant growth in some of the non-traditional export industries. One example is the information and communication technology (ICT) industry, which has, during the past decade or so, grown to become one of the largest export sectors in Uruguay, with its size growing from 2 percent of total exports at the beginning of the boom years to the current level of over 10 percent. Notably, the capital city Montevideo has become a leading software development/outsource center in the region, exporting primarily (over 50 percent) to the U.S. market, but with an increasingly diversified range of destinations. Meanwhile, after the large investment by UPM, a Finnish forest industry company, in the mid-2000s, cellulose pulp has emerged as another high-growth export industry. The introduction of this new industry has also had a significant impact on the land usage in Uruguay, with an increasing amount of agricultural land being replaced by forest area.
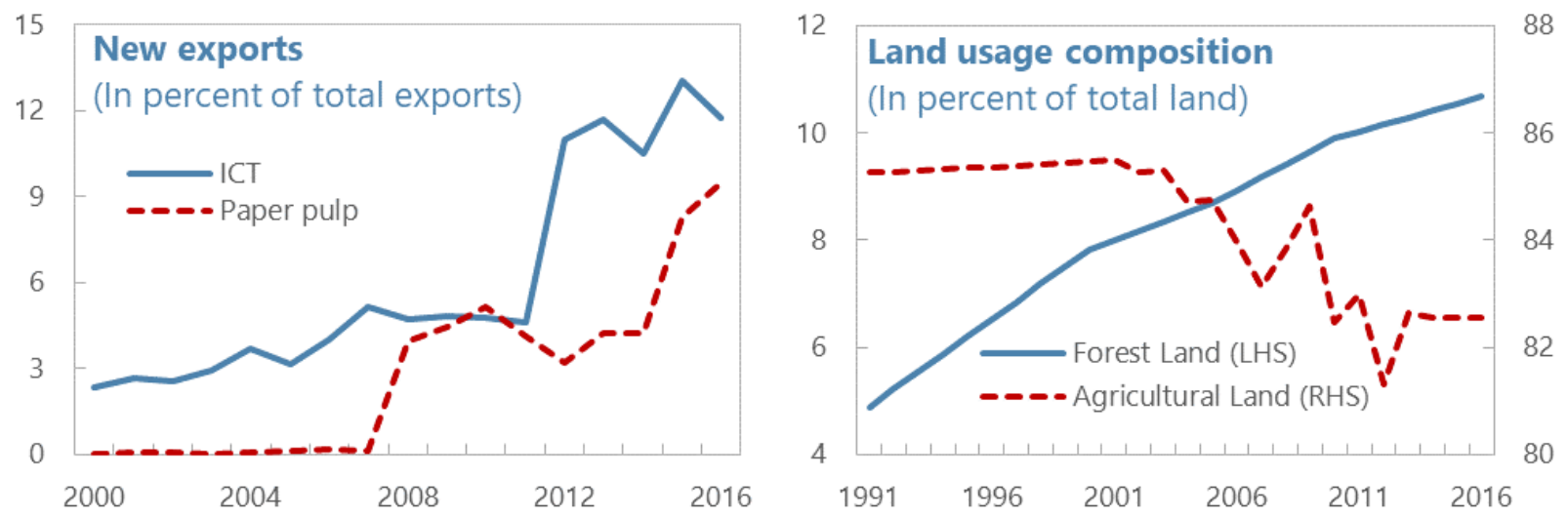

The growth of new industries has been supported by government policies. During the boom Uruguay implemented specific government incentives to encourage the growth of new export industries. For example, exports of software and related services are 100 percent

\footnotetext{
${ }^{3}$ Also see the Selected Issues Paper for IMF's 2016 Article IV Consultation for Uruguay.
} 
exempted from income tax (Decree 150/2007). The operation of UPM in Uruguay has also benefited from a variety of incentives.

\subsection{Productivity Growth}

Total factor productivity (TFP) growth seemed stronger during the boom years. The measured $\mathrm{TFP}^{4}$ saw an increase over the boom period. However, there is a very high correlation between output growth and estimated TFP growth in Uruguay, reflecting the positive termsof-trade shock, which has reversed after 2014 (see IMF country report 18/24 for a detailed discussion). After 2014, the estimated TFP growth has declined substantially.

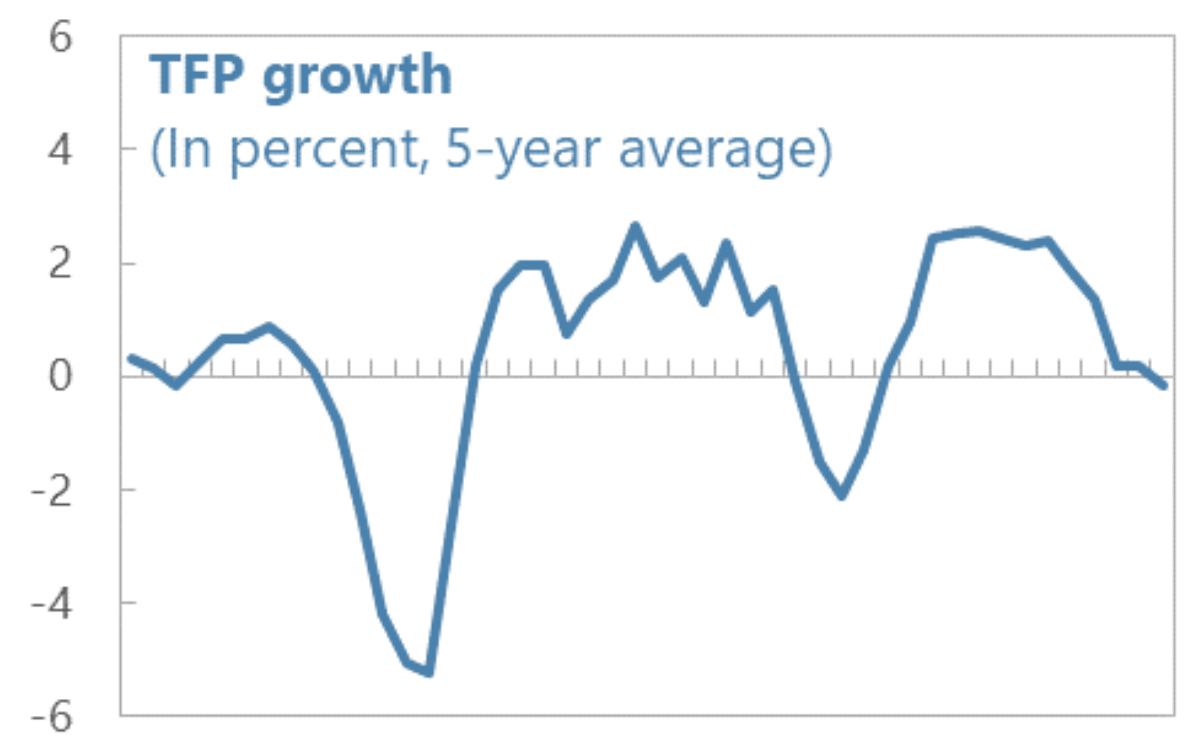

1972197719821987199219972002200720122017

\section{Relative Importance of Different Growth Drivers}

Although it is difficult to precisely decompose the cumulative increase in GDP during the boom into various parts mentioned in the previous section, the paper ran a numerical exercise to gauge their broad magnitudes.

\footnotetext{
${ }^{4}$ TFP calculated by Penn World Tables is used.
} 
Here's how the impacts of different growth factors are calculated:

- Supply side factors: i.e. sectoral contributions to growth from ICT, agriculture, tourism. Their contribution is calculated as the magnitude of the real increase in the export of that sector during 2004-2014, divided by the total increase in real GDP over the same period.

- Exchange rate effect: Selected Issues Paper for Uruguay by the IMF (2016) estimated the exchange rate appreciation's impact on GDP for Uruguay. The present paper used their estimated coefficient, multiplied by the rate of nominal appreciation during 2001-2014, to calculate the growth impact of appreciation against the USD.

- Rebound effect: First, real GDP growth is regressed on its lag over 5-year intervals. The rebound effect is then calculated as the difference between the growth rate for the 5 years before the boom and the historical average growth rate, multiplied by the estimated regression coefficient.

Positive terms of trade shocks, rebound from the crisis, and emergence of new sectors are the most important factors explaining the 2004-14 boom. The estimation shows that the impact from the rebound accounts for about 16 percent of the boom years' growth premium, i.e. the amount of growth that is beyond the historical average. And over 20 percent of the growth premium during the period can be directly attributed to the rise of various agricultural commodity exports, such as in soybean and livestock. ${ }^{5}$ In addition, other factors resulting from the positive movement in terms of trade - exchange rate appreciation, increasing demand from Argentina- explains over 15 percent of the growth premium. Meanwhile, the export growth from the new industries, i.e. ICT outsourcing and paper pulp, accounts for about 14 percent of the growth premium.

These estimations should be interpreted with caution and used as broad guidance. The estimates are prone to several biases. First of all, it is difficult to separate the impact

\footnotetext{
${ }^{5}$ This captures both price and quantity effects.
} 
of one factor from another. For instance, rise in commodity prices stimulated investment demand in the agriculture sector, which in turn raised productivity and production capacity of the sector. Therefore, depending on one's perspective, the direct and indirect impact of the positive terms of trade shocks is likely underestimated. Similarly, external investment inflows also contributed to the appreciation, and therefore indirectly impacting domestic demand. In addition, it is difficult to isolate the effect of exchange rate appreciation on domestic demand from other factors that boost growth, due to simultaneity bias. Overall, the contribution of the positive commodity price shock is likely understated.

\section{Sustainability of Growth Drivers}

The longevity of all growth drivers is not equal. Looking at the various factors that contributed to the boom, it is not difficult to see that some factors are more sustainable than the others. Identifying the more sustainable growth drivers will help us think about how to preserve and strengthen these drivers to sustain long term growth. At the same time, examining the functioning of the transitory growth drivers can shed light on how to better capitalize on the temporary growth opportunities to enhance the country's long-term economic potential.

\subsection{Sustainability of Supply-Side Factors}

Agricultural commodities are likely

to provide less support to growth over the long haul. First of all, despite the price surge during the 2000s, real agricultural commodity prices empirically display a trend decline over the long run, partly

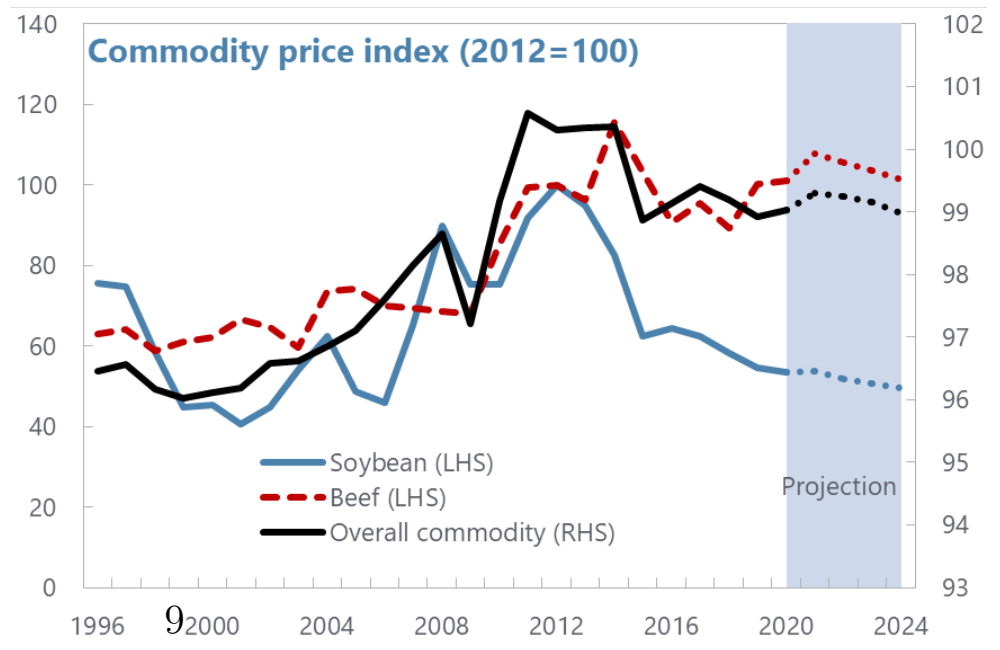


owing to the consistently rising

productivity of the sector from

technological advances. ${ }^{6}$ The re-

cent forecasts from the World Economic Outlook also points to a subdued medium-term trend for commodity prices. ${ }^{7}$

Secondly, data shows that the growing demand from China explained over 60 percent of the world demand increase in soybeans in the previous decade and a half. Yet with the slowing down of China's growth, soybean price has been on the decline since 2013, and the trend may continue.

Meanwhile, comparing the agricultural export sector of Uruguay with that of the neighboring countries further raises sustainability concerns. Although the growth in Uruguay's soybean exports had been initially exponential during the boom years, partly aided by the country's geographical advantage as a regional logistics hub, neighboring countries, Paraguay and Brazil in particular, have shown to be strong competitors in the industry, in terms of both cost and productivity. As the market price came down after 2013, Uruguay's soybean exports have decline correspondingly, ${ }^{8}$ while those of some neighboring countries continued to grow. What caused this difference in responses to the price drop? One likely reason, as confirmed by conversations with private sector firms, is the higher production cost-and consequently, lower margin - of Uruguay's exporting firms in the sector, compared to their counterparts in Brazil and Paraguay. Higher costs increase firms' vulnerability to adverse price shocks, and reduces firms' incentive and capability for long-term investments. In the following sections, the paper will discuss some of the potential causes of the higher cost structure of Uruguayan firms.

Without increasing investments driven by strong external demand and elevated prices, productivity growth in the agricultural commodity sector alone may not be sufficient to

\footnotetext{
${ }^{6}$ See, for example, Harvey, Kellard, Madsen and Wohar (2017).

${ }^{7}$ See, for example, the commodity price forecasts of the World Economic Outlook for October 2020.

${ }^{8}$ One may argue that some of the decline can be explained by weather shocks. Though that explains the export volatility more than the trend.
} 

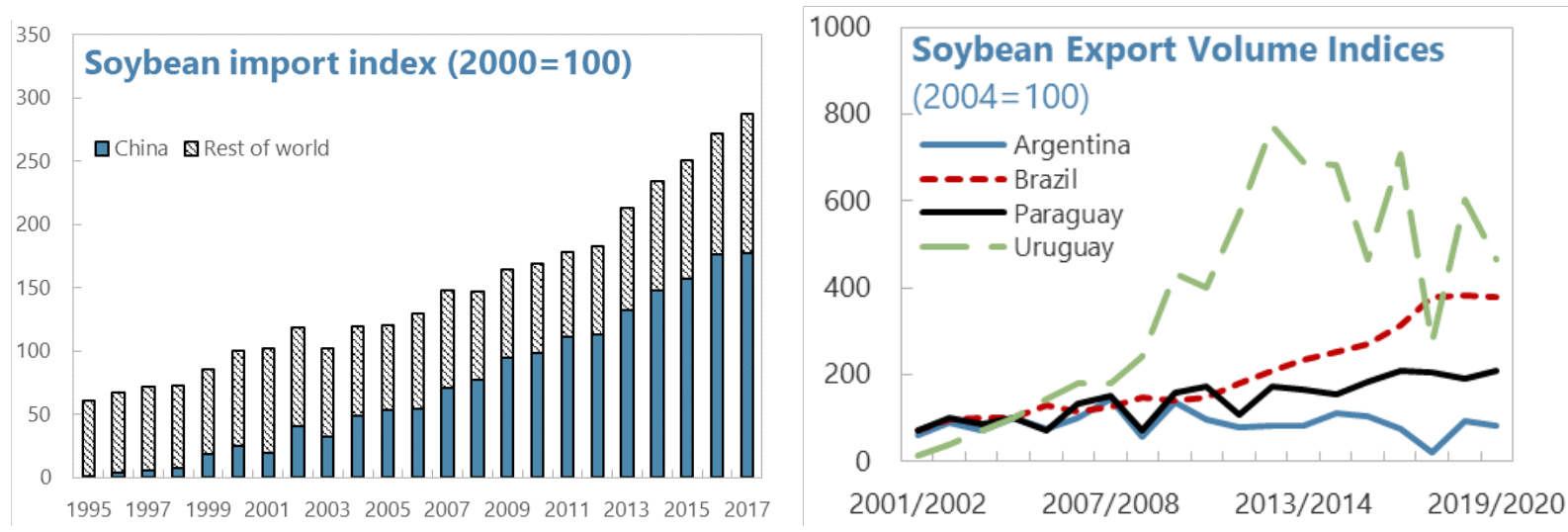

support sustained economic convergence. For instance, soybean productivity as measured by output per planting area is already close to the technological frontier, as represented by the sector's productivity in the US. And historically, the U.S. soybean sector productivity has been growing at an average rate of 1 percent per year. As such, the productivity growth in the sector would be insufficient to support economic convergence with advanced countries.

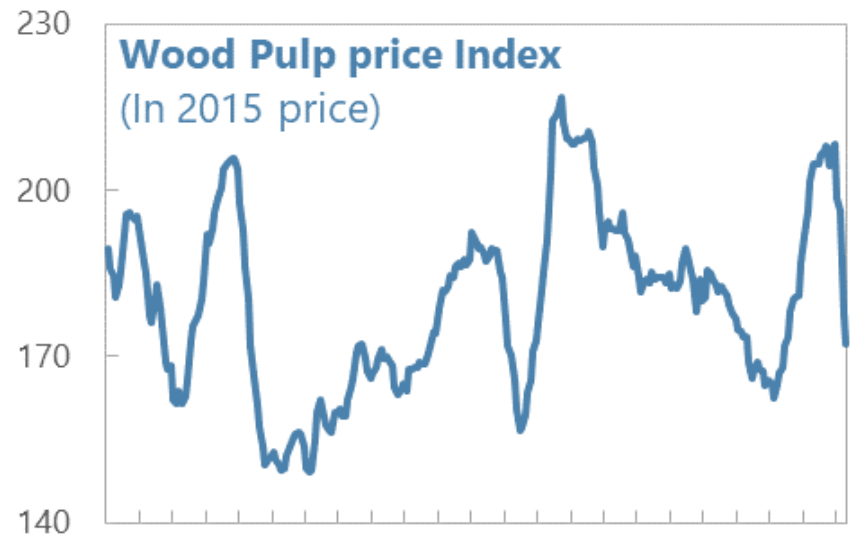

199719992002200520082010201320162019

Other emerging export industries may provide a sustaining source of growth, but they are not without challenges. The forestry and paper pulp industry enjoys relatively stable export prices $^{9}$ and steadily increasing world demand over the medium term. With the second pulp mill investment from UPM, the industry is poised to become the largest exporting industry in Uruguay. The growth of the industry is also expected to positively affect regional income convergence within the country, as its operation primarily locates in the less-developed, inland part of Uruguay. However, aside from a one-time, level effect on GDP from the new pulp mill, the industry's long-run impact on growth will depend

\footnotetext{
${ }^{9}$ This is partly due to the long production cycle of the industry from tree planting to pulp manufacturing. Thus in any given year, there is relatively few surprises on the supply side, compared to more traditional agricultural commodities.
} 
on to what extent it is able to stimulate the growth of other local, auxiliary industries. That in turn, is affected by the various structural constraints of the Uruguay economy, which will be discussed in the next section.

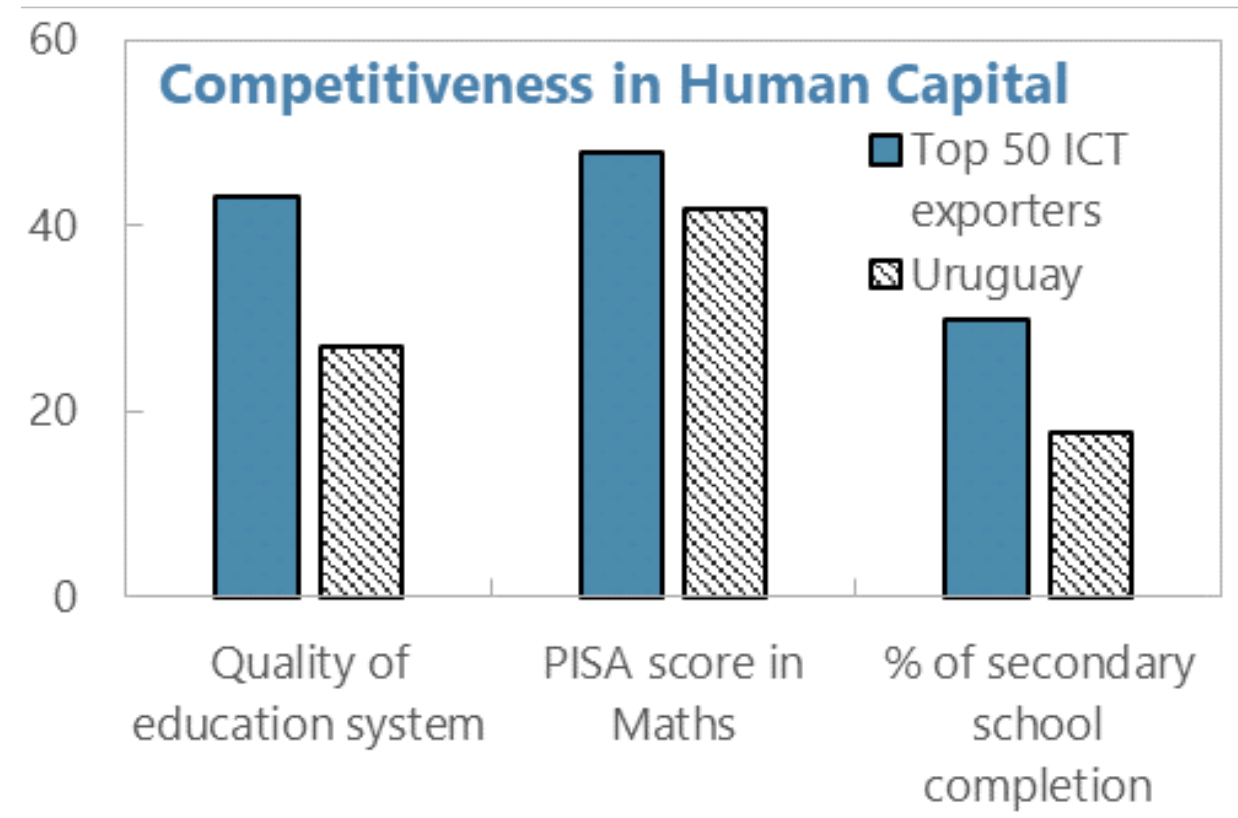

On the other hand, the growth prospect of high value-added service exports will depend on the cost, quality, and quantity of labor supply. Over the boom years, the ICT industry rose to become one of the fastest growing export sectors. The comparative advantage of Uruguay in the sector stems from its relatively good telecom infrastructure and its welleducated workforce, in particular compared to other countries in the region. However, data shows that compared to other top ICT exporting countries in the world, Uruguay lags behind in measures of education quality, such as secondary school completion rate and PISA scores in science and math. The quality and quantity of labor supply going forward may pose a challenge to the sector's long-term competitiveness. Effectiveness of the labor market to allocate workers to high-productivity firms and sectors, which will be discussed in the next section, will also influence the sector's international competitiveness. 


\subsection{The Role of Inflation And Real Exchange Rate}

The relationship between growth and exchange rate is a complicated one. During the boom, nominal appreciation has supported growth in the short term. As a small open economy with a limited domestic market size, the high growth episodes in Uruguay are typically led by positive external demand and terms of trade shocks. Thus it's no wonder that a surge in growth is almost always followed by nominal exchange rate appreciation, as historical data shows. And as mentioned in section 2.2.3, the nominal appreciation serves to distribute the dividend of external demand windfalls across the population, via de facto increases in income. And the subsequent lift in domestic demand further stimulates growth.

Theoretically, other things equal,

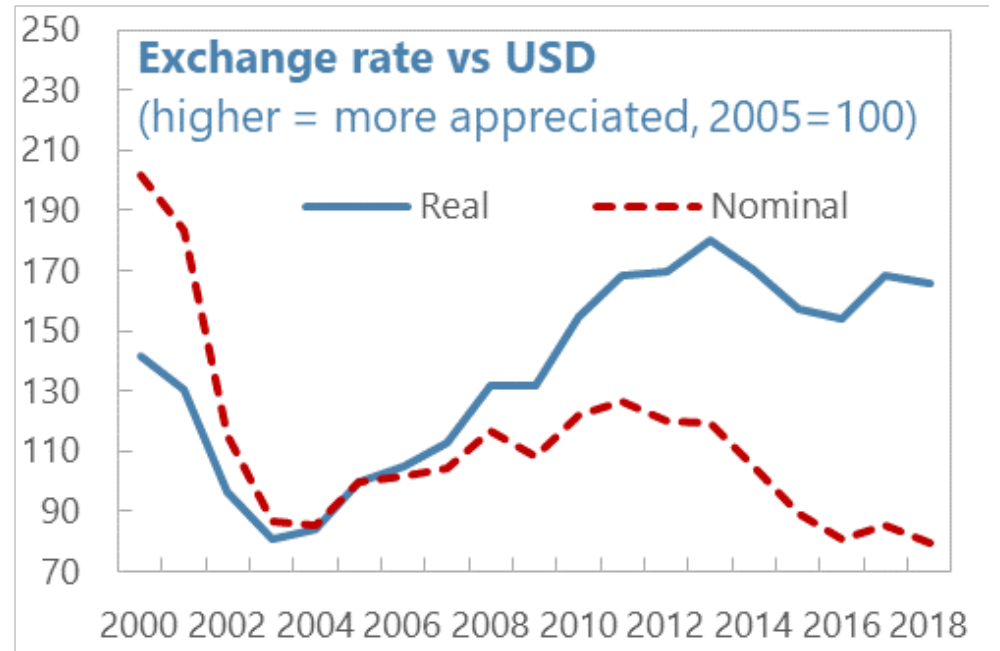
the nominal appreciation wouldn't necessarily affect the real exchange rate- as imports become cheaper, it would put downward pressure on inflation, and thus cancel out the effect of nominal appreciation on the real exchange rate. In reality, however, the opposite happened. During the commodity boom pe-

riod (2004 to 2014), Uruguayan peso appreciated in real effective terms by 47 percent, and in real terms against the U.S dollar by about 100 percent, much higher than the nominal appreciation- implying a growing positive inflation gap between Uruguay and most of its trade partners.

While economic competitiveness depends on a broad set of structural factors, high inflation, which leads to a persistently appreciating real exchange rate, directly increases the production cost of the export sector, reduces firms' profit level and capacity for future in- 
vestments, and makes the tradable sector more vulnerable to adverse export price shocks. ${ }^{10}$ This effect may be hard to observe during the boom period, when the aggregate demand is high. But it may become more obvious when the external demand stimuli are no longer present. $^{11}$

The upward bias of inflation in Uruguay seems to prevail regardless of economic cycles. Following the end of the commodity price boom, while the appreciation of nominal exchange rate was reversed, the real exchange rate remained elevated, largely due to the inflation deferential with many trade partners. This may have contributed to the "sudden stop" in growth after 2014, and the difference in response to price shocks of the Uruguayan agricultural commodity sector, compared to those in some neighboring countries, as mentioned in Section 4.1.

Consistent with anecdotal observations, results from a SVAR model comparing Uruguay and its regional peers show that inflation and real exchange rate both respond positively following positive external price shocks. However, this pattern is asymmetrical- negative export price shocks do not lead to the lowering of inflation or real exchange rate in Uruguay. (See Annex II for details.)

Although there are many reasons for the upward bias in inflation, one contributing factor may be the close linkage with the Mercosur market, Argentina in particular. Over the past two decades Uruguay has significantly diversified its international economic relations, but the tie with the regional market remains substantial, especially in the tradeable services sector. The prices of tourism and other related services tend to be locally determined, rather than globally set as in the case of most tradable goods. Due to these sectors' predominant reliance on Argentinian demand, the fluctuations of the Argentinean economy may directly impact the price level of the non-tradable sector in Uruguay, which feeds into inflation. And when the economies in the region are hit by the same external shocks, e.g. a surge in commodity

\footnotetext{
${ }^{10}$ Also see Uruguay's Selected Issues Paper on exchange rate and competitiveness, for the IMF 2018 Article IV Consultation.

${ }^{11}$ See Magud and Sosa (2013), Oreiro, Basilio and Souza (2014), Aghion, Bacchetta, Ranciere, and Rogoff (2009).
} 
prices, the pressure on inflation and real exchange rate tends to come from both global and regional levels, amplifying their impact. However, the opposite didn't happen when the external demand dropped- inflation did not come down when the terms of trade shock turned negative. One reason for this pattern may be the prevalence of wage indexation to past inflation, which creates a feedback loop that makes it harder for inflation to adjust down.

\section{Structural Factors for Growth Sustainability}

To improve the sustainability of supply-side growth drivers, structural reforms that increase the dynamism of the domestic private sector are needed. A macroeconomic environment that provides stability and flexibility for private sector firms help strengthen the supplyside growth drivers that are mentioned in the previous section. Identifying what Uruguay's strengths and weaknesses are in terms of the structural factors that define the economic environment is a helpful exercise in this regard.

Comparisons with other countries that were once at a similar development stage can help identify the focus of structural reforms. Conventional wisdom in economic growth often points to the general direction of reforms without taking into account the context of development stages. For example, although it may be obvious that an educated workforce is good for growth compared to an uneducated workforce, the education level of workers also tends to be endogenous of economic development itself. Thus, to identify the appropriate reform priorities, it is helpful to make cross-country comparisons of structural factors conditional on a country's development stage.

A high-growth peer group is selected for the comparison. The peer group is chosen by first identifying the countries that were once at a similar development stage - proxied by their GDP per capita relative to the U.S. level-to Uruguay in $2018,{ }^{12}$ at any point in time since

\footnotetext{
${ }^{12}$ Defined as GDP per capita relative to the US falling within a 10 percent band around the level of Uruguay 2018.
} 
1950. Within this group, the countries with the fastest speed of economic convergence ${ }^{13}$ in the subsequent 10 years are then chosen as the high-growth peer group, provided that there hasn't been any significant reversal in the country's convergence process up to 2018.

One drawback of the comparison countries being in different time periods is that the data for earlier time periods may not always be available for some variables, e.g. PISA score on education. If the data for a designated year is not available, the paper substitutes it with the earliest available data. But this may create some bias against Uruguay, since we wouldn't be strictly comparing countries at a similar development stage if data for later years have to be used for the more advanced countries. Therefore, the paper also includes in the comparison the contemporaneous trade competitors of Uruguay. These are defined as the countries that have an export basket similar to that of Uruguay. The resemblance between two countries is calculated as the cosine similarity score between the vectors of "revealed comparative advantage" scores for all SITC 4-digit goods, for the two countries. ${ }^{14}$

Uruguay is compared with the two peer groups across a wide range of structural factors. They are categorized into four groups- factors that may affect capital input, labor input, human capital, and total factor productivity of the economy. Annex IV lists the data sources of all variables. It should be emphasized that especially for the high-growth peer group, the comparison is done between Uruguay in 2017/2018 and the high-growth countries when their income level was close to that of Uruguay today. When the historical data for a country-year combination is not available, the paper uses data of the closest available year instead.

\subsection{Investment and Capital Accumulation}

Investment rate in Uruguay is low compared to peer groups. Investment rate has quickly declined after the boom period, from its peak of 25 percent of GDP in 2012 to around 16 percent in $2017,{ }^{15}$ which is close to the historical average rate in Uruguay. And even the

\footnotetext{
${ }^{13}$ Defined as the relative GDP per capita growth being higher than 70 percent of the whole sample.

${ }^{14}$ See Annex III for the country/year combinations included in the high-growth peer group and the trade rival group.

${ }^{15}$ For cross country comparability, PPP adjusted data from the Penn World Table are used.
} 
peak investment rate during the boom years was still lower than the average of those in high-growth peer countries.
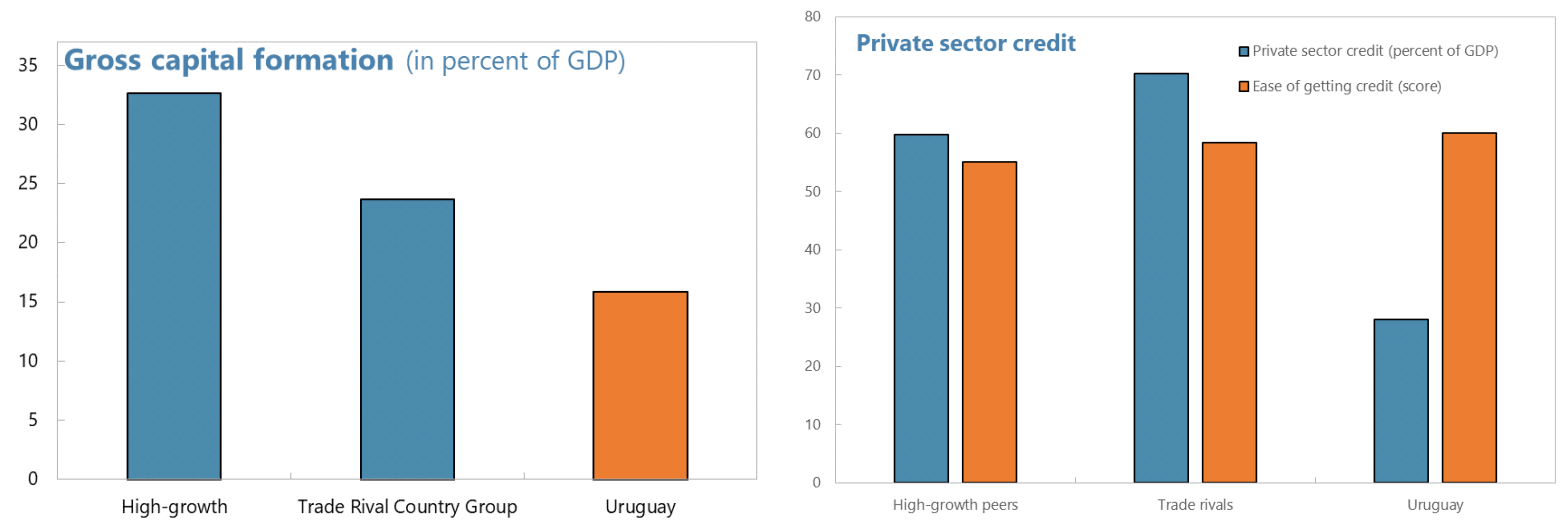

Credit to the private sector is also low. Although obtaining financing is not perceived as difficult according to survey data, the private sector credit to GDP ratio is perennially lower than in most peer countries. This may reflect a low demand for real investment, the financing model of private businesses, and other structural issues that may lead to lower intermediation, such as limited banking sector competition and high lending rates.

\subsection{Labor Market}

Uruguay fairs relatively well regarding labor welfare indicators, inequality, poverty, and informality (see SIP on Labor market conditions). As Uruguay continues to close gaps in living standards with advanced economies, it faces the challenge of maintaining social protection for workers while preserving economic efficiency and growth. These achievements, an important part of social cohesion, should be maintained. At the same time, Uruguayas a small open economy subject to large macroeconomic shocks (including those leading to loss of competitiveness) - needs an adequate degree of labor market flexibility to enable sectoral reallocation of workers to jobs needed for productivity growth (micro flexibility) and to maintain employment at a high level (macro flexibility).

Survey data indicate that Uruguay could benefit from further increasing its labor market 

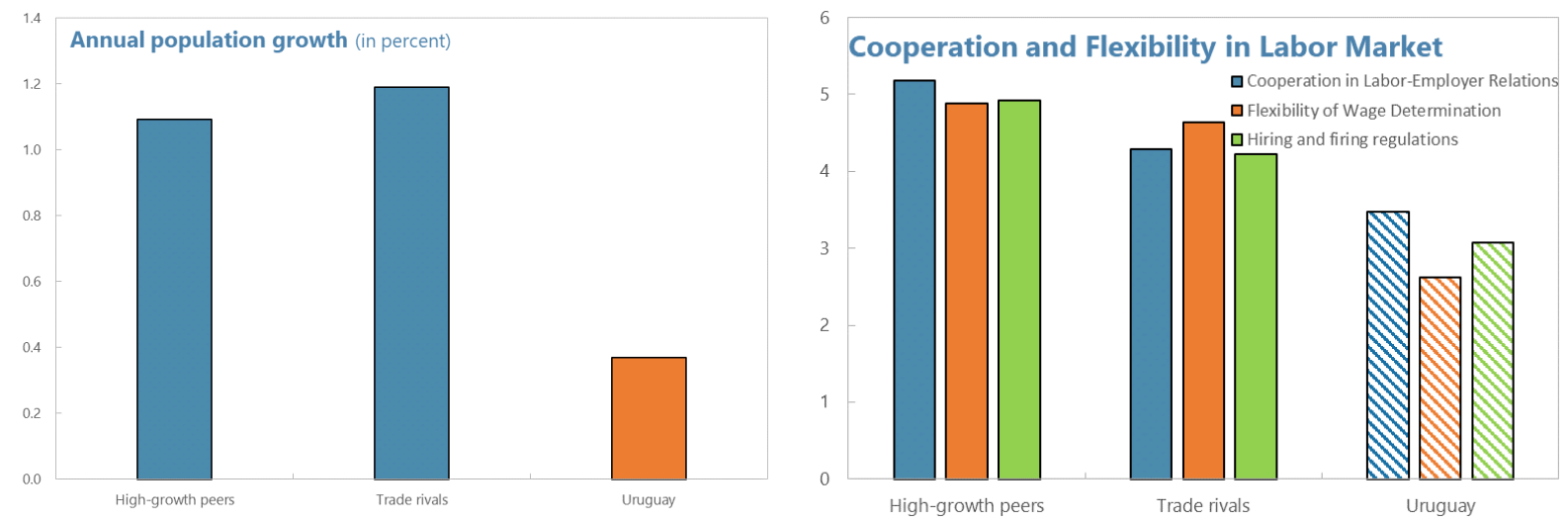

efficiency. According to survey data by the World Economic Forum, Uruguay is perceived as less flexible than both high-growth peers and trade rivals, in terms of wage flexibility and hiring and firing regulations. In addition, cooperation in labor-employer relations appear to be less favorable.

Population growth is low compared to high-growth countries at a similar development stage. The quantity of human capital available in an economy, an essential input for sustainable growth, is strongly correlated with the growth of working-age population. Past researches have also shown that population growth may positively affect productivity growth and speed of innovation, by facilitating the communication and spread of new ideas. It is an established empirical observation that birth rate tends to be negatively correlated with a country's income level, which helps explain the lower population growth in Uruguay compared to most other countries in the LAC region. However, even compared to the high-growth country group at a similar development level, Uruguay has a slower population growth, as well as an older population.

\subsection{Human Capital}

Although quantitative provision of education in Uruguay is at par with the high-growth peers, the quality of human capital lags behind. Uruguay scores similarly to the group of high-growth peer countries in measures of education quantity, such as the average years of 
schooling. However, survey data of private sector stakeholders indicates that the perceived quality of the education system is lower than in both high-growth peers and trade rivals. In addition, compared to the high-growth peer group, Uruguay scored 12-15 percent lower in the math and science scales of the PISA assessments, which measure educational achievements in secondary schoolers. This is consistent with the observation from the previous section that the quality of education, which affects the supply of future human capital, in Uruguay lags behind other countries that are also large ICT service exporters.
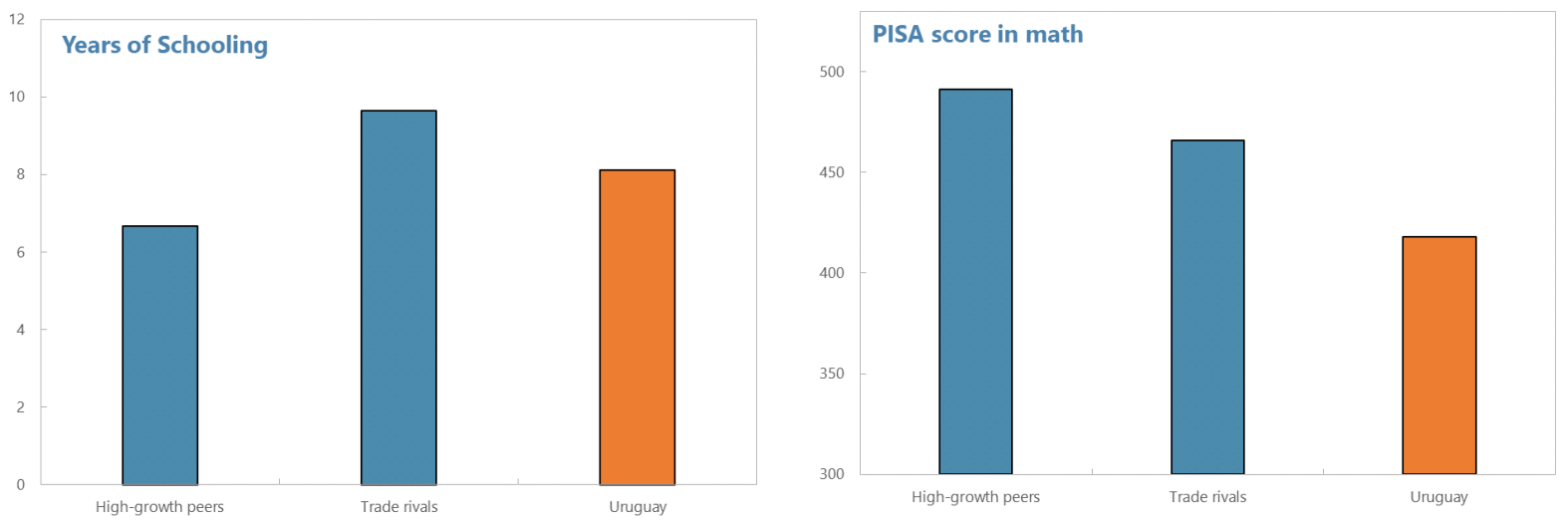

\subsection{Productivity}

TFP growth is lower than in the high-growth peers. Although the estimated TFP growth increased during the boom (reflecting the terms-of-trade shock), over the past 10 years, the average TFP growth was a little over 1 percent per year, close to the country's historical average, and currently is estimated at around 0-0.5 percent.

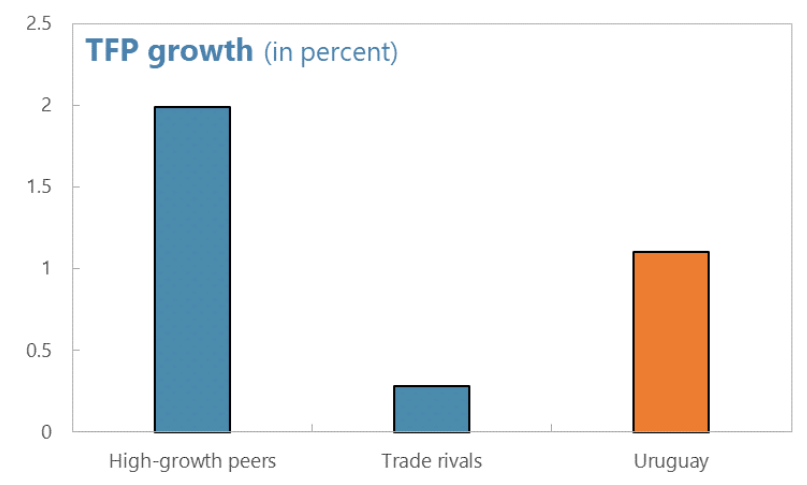

The TFP growth rate is lower than the average of the high-growth peers at a similar development level, though higher than the average of trade rivals. The following sub-sections will examine the various structural factors that may 
impact productivity growth.

\subsection{Institutional Quality}

Uruguay compares favorably in public

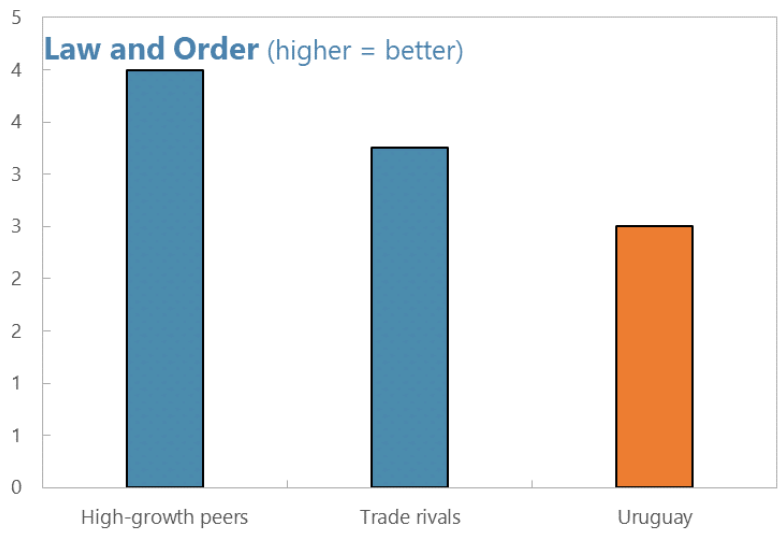

governance. The country scores better than the average level of both comparison groups in the measures of judicial independence and corruption within the political system. The latter is shown in past researches to likely deter foreign investments, distort price signals in the economic environment, and reduce the efficiency of both public and private sectors. There is however room for improvement in terms of law enforcement, which might reflect rising crime rate in the country.
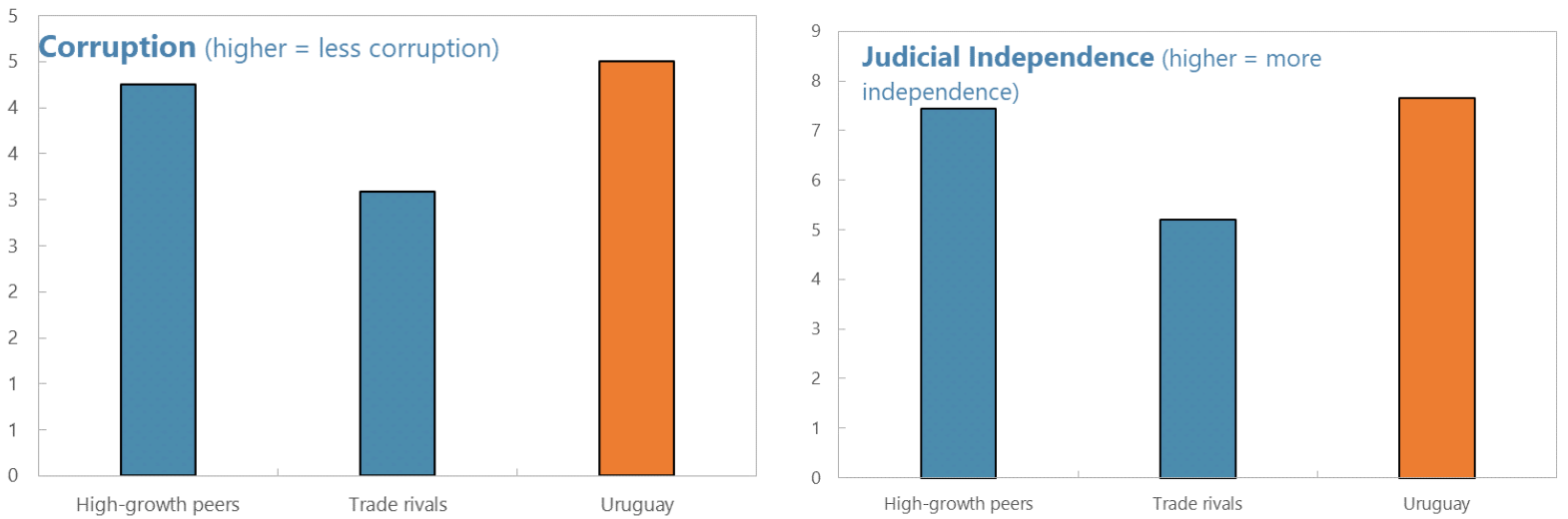

\subsection{Infrastructure}

The quality of transport infrastructure trails behind high-growth peers and has declined over the years. The quality and quantity of transport infrastructure are crucial for reducing export costs and bridging regional economic inequality. Although the stock of infrastructure capital 
is not low in Uruguay, due to heavy investments in the late-1970s, infrastructure spending has dropped significantly since the mid-1980s and stayed at an average level of around 4 percent of GDP per year - and for the last few years it fluctuated at around 2 percent of GDP. The boom years of 2004-14 did not see any significant increase in infrastructure investments. As a result, the overall infrastructure stock has not improved, or even slightly declined, depending on the depreciation rate one assumes, over the past 30 years. This helps explain the low score of perceived infrastructure quality compared to the peer groups.
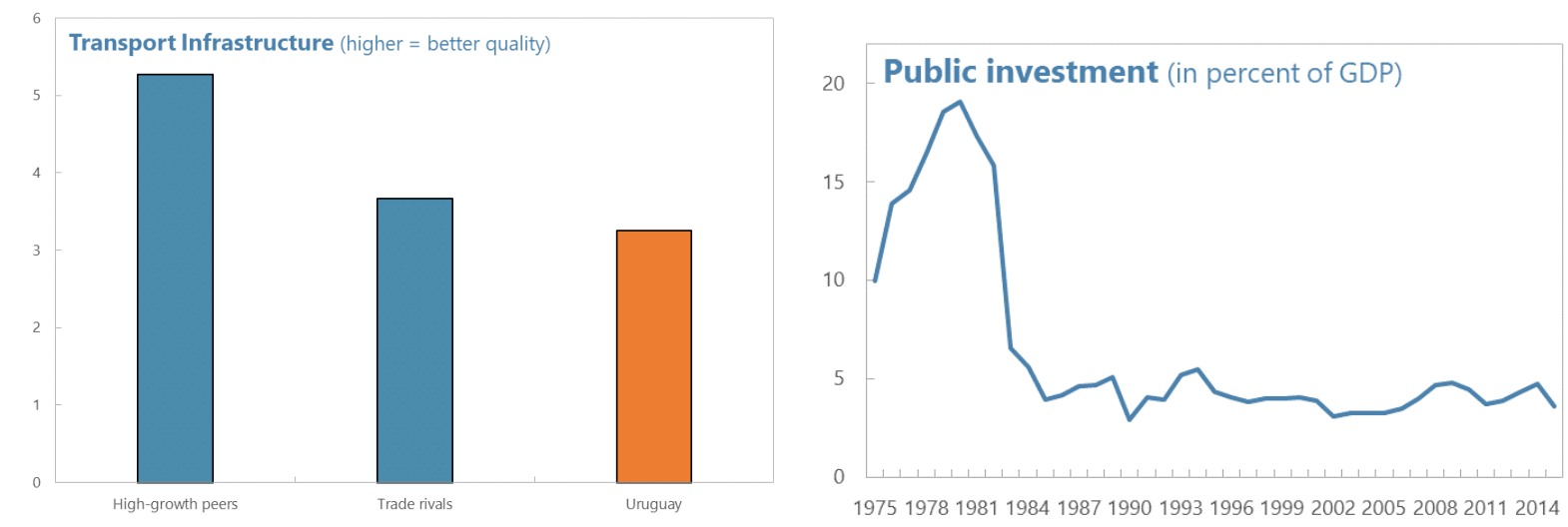

\subsection{Business Environment}

Uruguay is broadly at par with the comparison groups regarding some aspects of the business environment, but there is room for improvement. These include, for example, transaction cost associated with regulatory compliance for tradable sector, tax burden, and licensing and permitting procedures. Moreover, many measures of the business environment have seen improvements of various extents over the boom years, including the overall tax and contribution burden, the quality of business regulations, and export costs. There is still room for improvement in further reducing compliance costs of international trade, (relative to high growth peers) and time and cost of registering property.

However, these improvements have not translated into higher dynamism of the private sector. New business activities, as measured by the number of new firm registrations per 

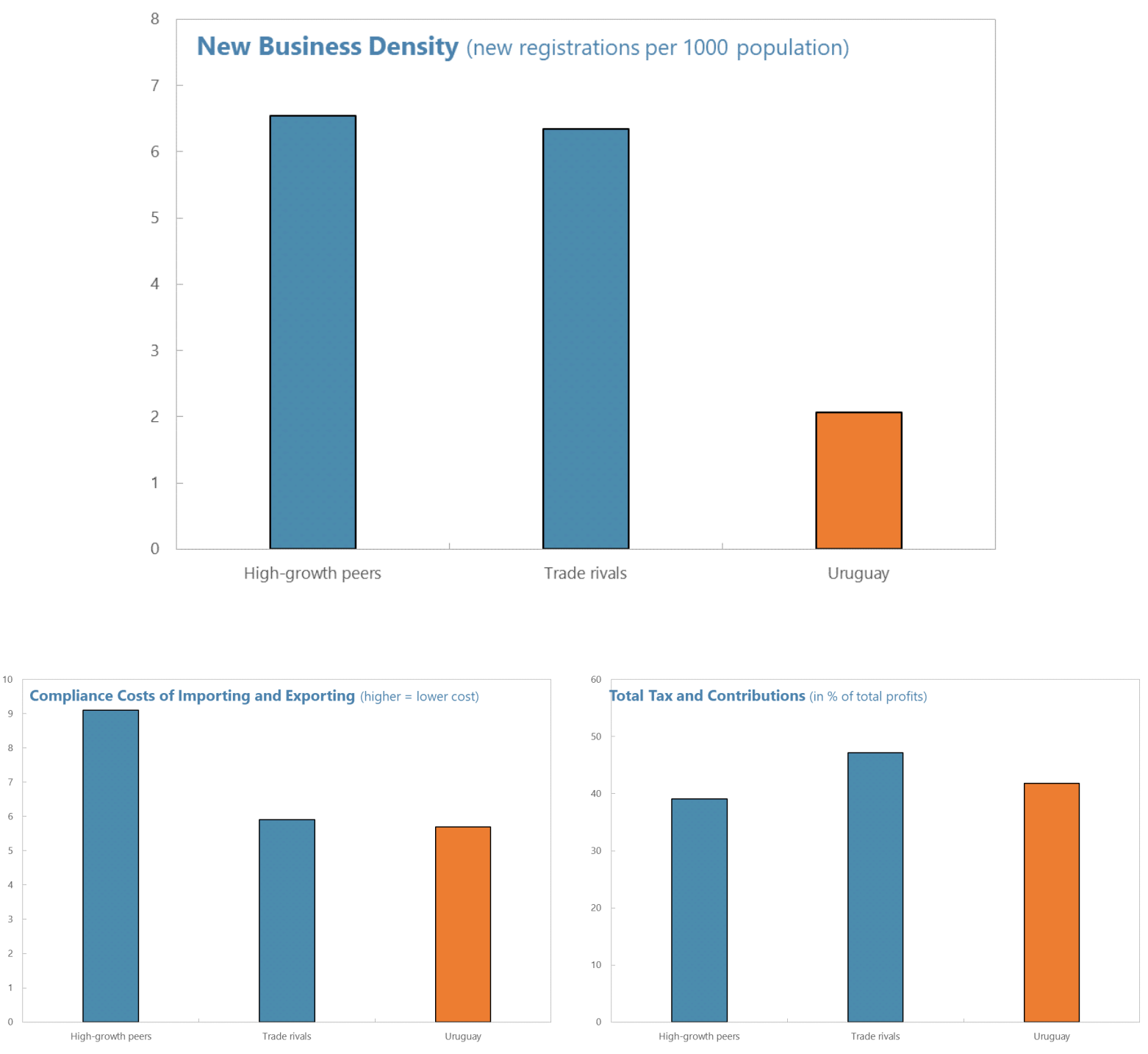

1,000 adult population, is 70 percent lower than both peer groups. Moreover, new business activities have been on a trend decline over the past 10 years.

\subsection{Macroeconomic Environment}

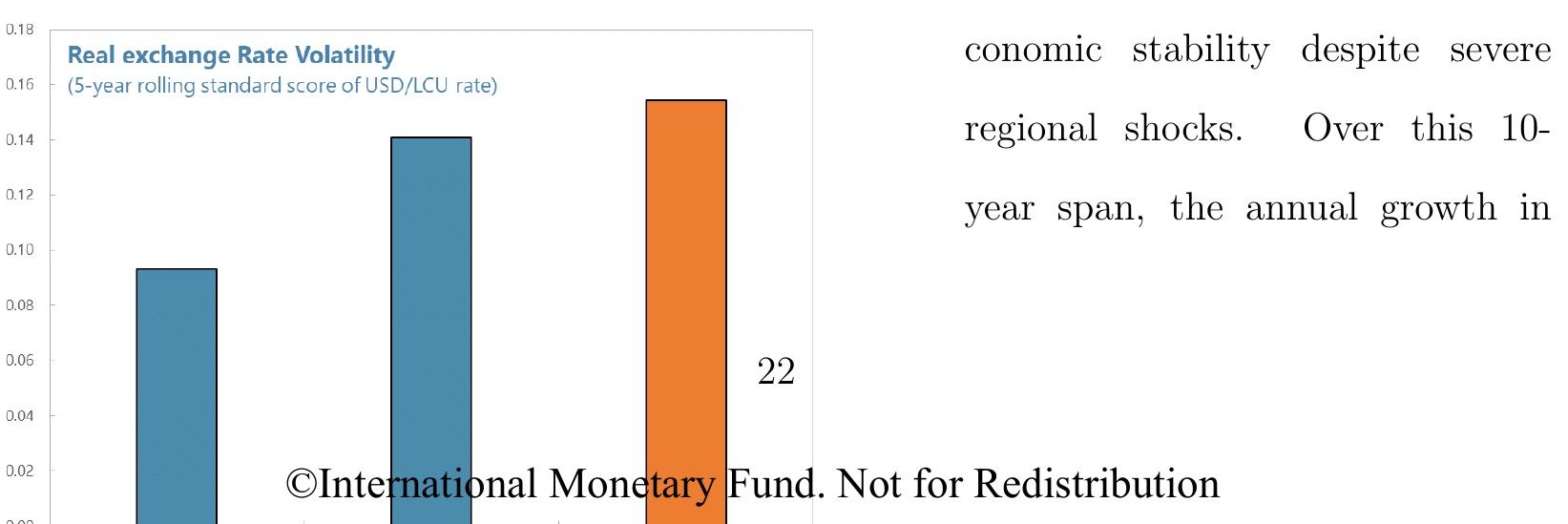



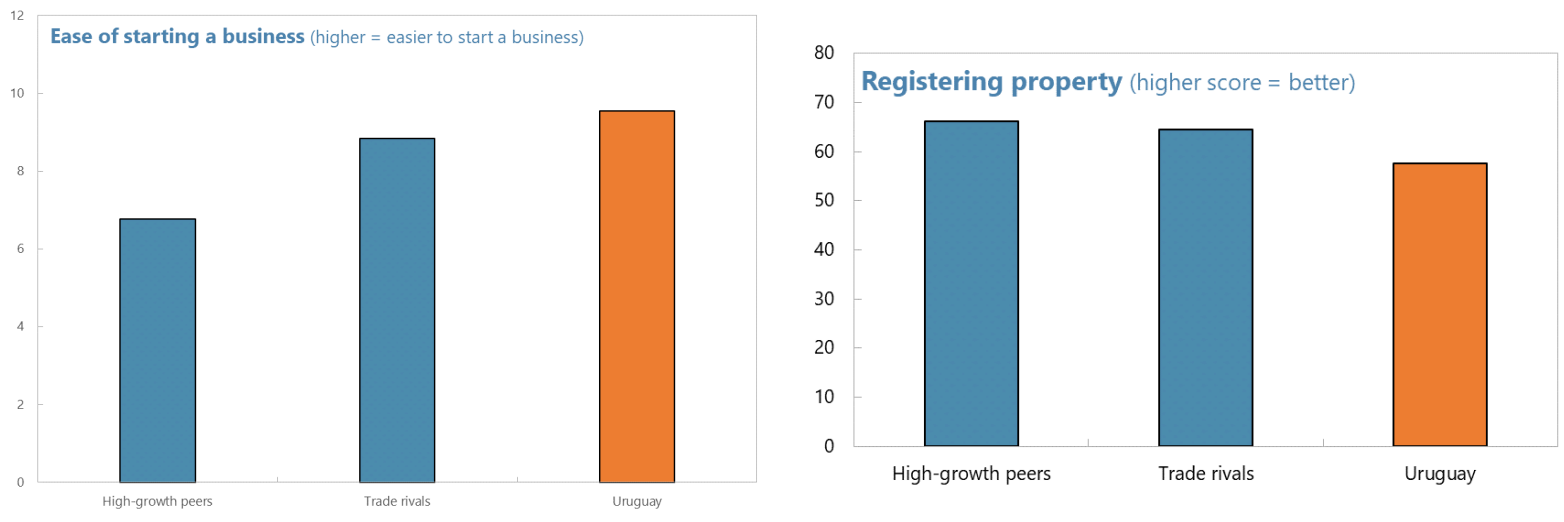

real GDP per capita averaged 4.9 percent, much higher than the 2.3 percent of Latin America and the Caribbean (LAC). In addition, despite the growth slow down,

Uruguay preserved its macro stability in the face of severe regional shocks. In particular, spillovers from Argentina have been limited to the real sector and exchange rate channels, reflecting its robust financial sector, which had markedly reduced its exposure to Argentina prior to the onset of the crisis.

There is still room for further improvements. Public debt level (non-financial public sector) and real exchange rate volatility are higher than the average levels of comparison groups. In terms of inflation, Uruguay has much higher inflation than its trade rival group (excluding Argentina) and high-growth peer group in recent years.

\section{Conclusion}

The economic boom in Uruguay over 2004-2014 was driven by a combination of positive external demand shocks, rebound from the crisis, and emergence of new sectors. The 10year growth acceleration starting in the mid-2000s was the biggest economic boom in the Uruguay history over the past half century. This boom was propelled by several overlapping 

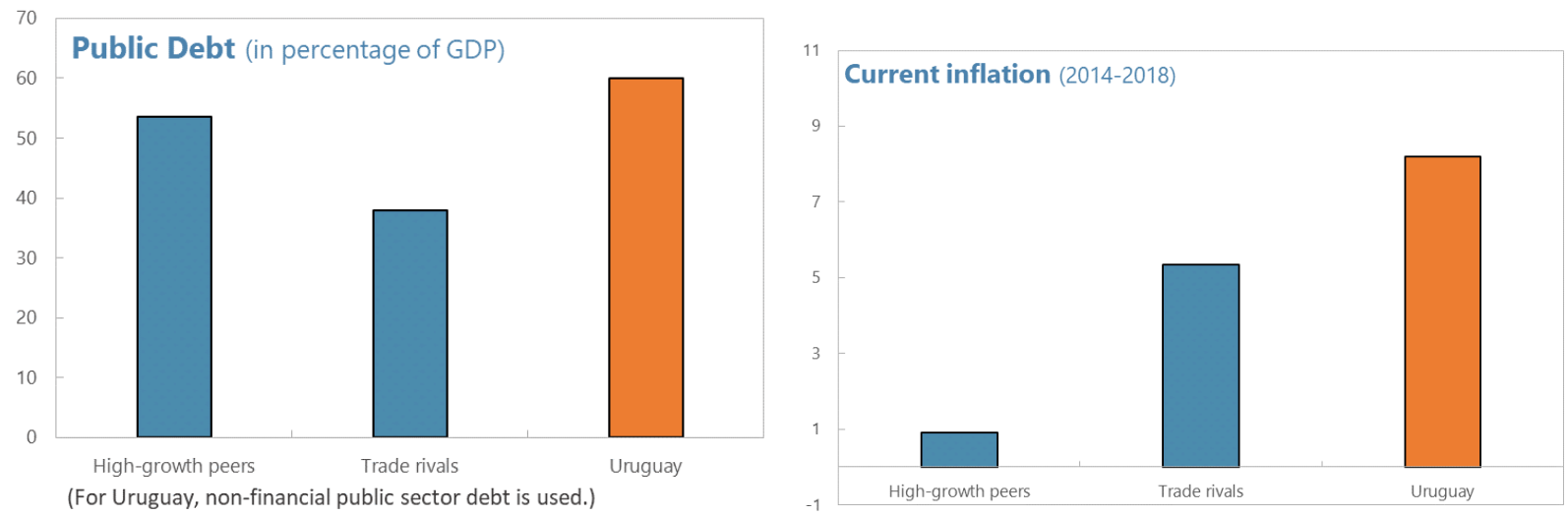

factors, including, but not limited to, a bounce back from the crisis in the early-2000s and the growth in external demand of commodities that boosted agricultural export prices, and emergence of new export sectors.

The external demand shocks were particularly strong because they came from both within and outside the region. Although the commodity price boom was primarily driven by the demand from outside Mercosur, demand from within the region increased as well. Because Uruguay's main trading partners in the region, Argentina and Brazil, are also prime beneficiaries of the commodity price boom. The latter manifested as increased capital inflow and demand on tourism, particularly from Argentina.

External conditions are no longer supportive. The commodity super-cycle ended in 2014 and the commodity prices are expected to remain subdued going forward. In addition, potential growth of the global economy and key trading partners of Uruguay (including China) is much lower than a decade ago. Furthermore, risks to the global growth are on the downside and Uruguay continues to be subject to large exchange rate shocks stemming from the region. Finally, prices of the some of the key export sectors (such as agriculture) may also be affected by a global trend decline, including due to productivity increases.

The emerging new export industries may prove to be a more sustainable driver of growth going forward. New export sectors such as ICT and related business services, as well as forestry and paper pulp, have grown in importance over the boom years but continued growth of new sectors would require leveraging strengths and eliminating the structural 
bottlenecks for private sector development.

Uruguay's institutional strengths are key for sustainable growth. These include the country's strong public governance and a stable regulatory environment for trade and foreign investment. In addition, the ongoing infrastructure projects (upgrading road networks and introducing a central railway) will help close the infrastructure gaps and set the ground for higher growth.

Structural policy reforms on key constraints to the private sector will help realize the potential of the new export industries and set the stage for inclusive growth.

- Strong, flexible, and equitable labor market is key to support inclusive growth in the face of low population growth and declining labor force participation. Further improvements in the efficiency and flexibility of labor market would help facilitate labor allocation to high productivity sectors, accommodate large negative shocks and incentivize employment.

- Quality and quantity of education should match the needs of skill-intensive new sectors.

- Low population growth and aging pressures could be alleviated by further raising female participation or facilitating integration of immigrants into labor market.

- Diversification out of the commodity sector is important for growth going forward ${ }^{16}$. Because of the large FDI investment in paper pulps in recent years, forestry is quickly becoming the new "soybeans" for Uruguay, as the export share of the latter declines. While the new FDI may provide a boost to the economy, replacing one agro-commodity with another in the export basket may not be the best case scenario in the long run. Diversification strategies should consider focusing more on the sectors that create higher value added and knowledge spillovers.

- While crime is still low relative to the regional peers, the recent deterioration in crime

\footnotetext{
${ }^{16}$ See the Selected Issues Paper of IMF's 2021 Article IV Consultation with Uruguay.
} 
statistics should be addressed before they become macro critical or affects perception on law enforcement.

A strong and credible macro policy framework is also essential for growth sustainability. Efforts to reduce debt and inflation and keep them at low levels will lay the foundations for structural reforms to flourish and also help reduce the appreciation bias in real exchange rate. 


\section{References}

Aghion, P., Bacchetta, P., Rancière, R., and Rogoff, K. (2009). Exchange rate volatility and productivity growth: The role of financial development. Journal of Monetary Economics, 56(4), 494-513.

Beetsma, R., Giuliodori, M., and Klaassen, F. (2008). The Effects of Public Spending Shocks on Trade Balances and Budget Deficits in the European Union. Journal of the European Economic Association, 6(2-3), 414-423.

Çebi, C. and Çulha, A. A. (2014). The effects of government spending shocks on the real exchange rate and trade balance in Turkey. Applied Economics, 46(26), 3151-62.

de Castro, F., Fernandez, L., 2013. The effects of Fiscal shocks on the exchange rate in Spain. The Economic and Social Review 44(2), 151-180.

Eichengreen, B. (2007). The real exchange rate and economic growth. Social and Economic Studies, 56(4), 7-20.

Hartmann Dominik, Christian Jara-Figueroa, Miguel R. Guevara, Alex Simoes and César A. Hidalgo, 2016, "The structural constraints of income inequality in Latin America," Integration \& Trade Journal, No. 40, June, p.70-85.

Harvey, D. I., Kellard, N. M., Madsen, J. B., and Wohar, M. E. (2017). Long-Run Commodity Prices, Economic Growth, and Interest Rates: 17th Century to the Present Day. World Development, 89, pp. 57-70.

Hausmann, Ricardo, Dani Rodrik and Andres Velasco, 2008, "Growth Diagnostics," The Washington Consensus Reconsidered, 324-355.

Magud, N., and Sosa, S. (2013). When and why worry about real exchange rate appreciation? The missing link between Dutch disease and growth. Journal of International Commerce, Economics and Policy, No. 04(02).

Oreiro, J. L., Basilio, F. A., and Souza, G. J. (2014). Effects of overvaluation and exchange rate volatility over industrial investment: empirical evidence and economic policy proposals for Brazil. Revista de Economia Política, No. 34(3), pp. 347-69.

Spilimbergo, Antonio, Alessandro Prati and Jonathan D. Ostry, 2009, "Structural Reforms and Economic Performance in Advanced and Developing Countries," IMF Occasional Paper No. 268 (Washington: International Monetary Fund). 


\section{Annex I. Augmented Dickey-Fuller Test}

The test is run by fitting the annual real GDP series $\left(y_{t}\right)$ to the following model:

$$
\Delta y_{t}=\alpha+\beta y_{t-1}+\gamma_{1} \Delta y_{t-1}+\gamma_{2} \Delta y_{t-2}+\cdots+\gamma_{k} \Delta y_{t-k}+\epsilon_{t}
$$

The null hypothesis $(\beta=0)$, i.e. GDP follows a random walk, is rejected at 1 percent level for all lag specifications except for $\mathrm{k}=10$. The table below presents the test statistics.

\begin{tabular}{|c|c|c|c|c|}
\hline Lags & $\begin{array}{c}\text { DF-GLS t test } \\
\text { stats }\end{array}$ & $\begin{array}{c}\mathbf{1 \%} \text { critical } \\
\text { value }\end{array}$ & $\begin{array}{c}\mathbf{5 \%} \text { critical } \\
\text { value }\end{array}$ & $\begin{array}{c}\mathbf{1 0} \% \text { critical } \\
\text { value }\end{array}$ \\
\hline 10 & -2.6 & -2.6 & -2.0 & -1.7 \\
\hline 9 & -2.6 & -2.6 & -2.1 & -1.8 \\
\hline 8 & -3.0 & -2.6 & -2.1 & -1.8 \\
\hline 7 & -3.8 & -2.6 & -2.1 & -1.8 \\
\hline 6 & -3.3 & -2.6 & -2.1 & -1.8 \\
\hline 5 & -3.0 & -2.6 & -2.2 & -1.9 \\
\hline 4 & -3.1 & -2.6 & -2.2 & -1.9 \\
\hline 3 & -4.0 & -2.6 & -2.2 & -1.9 \\
\hline 2 & -4.4 & -2.6 & -2.2 & -1.9 \\
\hline 1 & -4.3 & -2.6 & -2.3 & -2.0 \\
\hline
\end{tabular}




\section{Annex II. Commodity Export Price's Impact on Infla- tion and Exchange Rate}

This annex compares the impact of commodity export price shocks on domestic price level and exchange rate for Uruguay and for other countries in the region, using a SVAR model. Nine commodity exporting countries in Latin America are included in the comparison: Argentina, Bolivia, Brazil, Chile, Colombia, Mexico, Paraguay, Peru, Uruguay.

The empirical model is estimated based on quarterly data from 2000 to $2019 .^{17}$ The data source of most variables is the World Economic Outlook (WEO). The commodity export price index for each country is compiled using world commodity prices weighted by the country's commodity export basket. All variables are logged and first differenced to ensure stationarity.

The empirical model takes the following form:

$$
A_{0} Z_{t}=A_{1} Z_{t-1}+\mu_{t}
$$

$Z_{t}$ is the vector of variables of interest, and

$$
Z_{t}=\left[\begin{array}{llll}
\operatorname{cxp}_{t} & \operatorname{exr}_{t} & y_{t} & p_{t}
\end{array}\right]^{T}
$$

where $\operatorname{cxp}_{t}$ is the commodity export price index of the underling country, exr $r_{t}$ is the local currency to USD exchange rate, $y_{t}$ is the real GDP, and $p_{t}$ is the CPI index. Again, all variables are in the logged and first-differenced form.

$A_{0}$ is a $4 \times 4$ lower triangular matrix, with 1 on the main diagonal, and $E\left(\mu_{t} \mu_{t}^{\prime}\right)=\Sigma$. Equation (1) can be rewritten as

$$
Z_{t}=B Z_{t-1}+C \epsilon_{t}
$$

\footnotetext{
${ }^{17}$ Estimations were also run using longer time series starting 1980. Most of the results are not sensitive to changes in time coverage.
} 
where $B=A_{0}^{-1} A_{1}, \epsilon_{t}=\Sigma^{-1 / 2} \mu_{t}$, and therefore $E\left(\epsilon_{t} \epsilon_{t}^{\prime}\right)=I$. And $C=A_{0}^{-1} \Sigma^{1 / 2}$.

Since $B_{1 *}=\left[\begin{array}{llll}b_{11} & 0 & 0 & 0\end{array}\right]$, the model specification means that $\operatorname{cxp}_{t}$ follows an $\operatorname{AR}(1)$ process, i.e. the commodity export price index is contemporaneously only affected by a shock to itself, and not by innovations to any other variables. This is a realistic assumption. Though commodity exports is an important sector in the sample countries, considering their sizes, they should be considered as largely price takers of the world commodity market.

The model $\left(A_{0}, \Sigma, A_{1}\right)$ is estimated country by country, with the sample for each country spliting into two sub-samples- one with positive export price shocks, $\left(\Delta c x p_{t} \geq 0\right)$, and the other with negative price shocks $\left(\Delta c x p_{t}<0\right)$. Figures 1 and 2 plot the response of domestic prices to a positive and negative commodity export price shock, respectively, for each country.
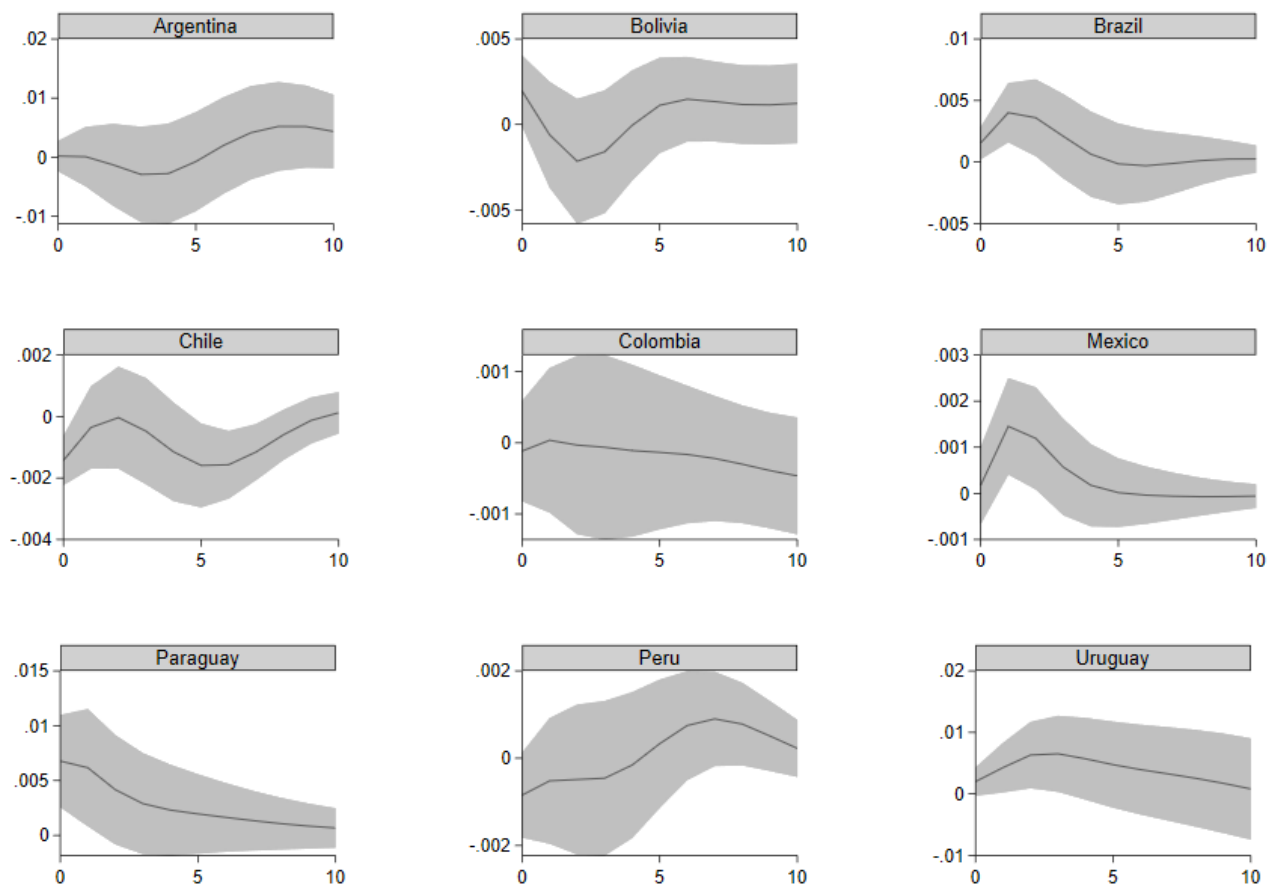

Response of inflation to positive export price shock, SVAR

Figure 1: Response of inflation to positive export price shocks

Theoretically the impact of a positive export price shock on domestic inflation can be ambiguous. On the one hand, the income effect of the export price shock increases aggregate 
demand, which puts upward pressure on inflation. On the other hand, the local currency tends to appreciate as export earnings increase, which creates downward pressure on inflation as imports become cheaper. Ultimately, which side wins depends on various economy-specific factors, such as the size of imported components in the domestic consumption basket, fiscal discipline of the public sector, and monetary and exchange rate policy choices.

For the majority of countries in the sample, Uruguay included, a positive commodity export price shock appears to lead to higher inflation. Still, as Figure 3 shows, in terms of magnitude and duration, the response of inflation in Uruguay to positive commodity export shocks is among the largest and most persistent compared to others in the sample. The same cannot be said when the export price shock is negative. As Figure 2 indicates, inflation does not appear to respond to negative export price shocks in a consistent pattern in Uruguay, and the magnitude of the response is smaller compared to the case of positive export price shocks.
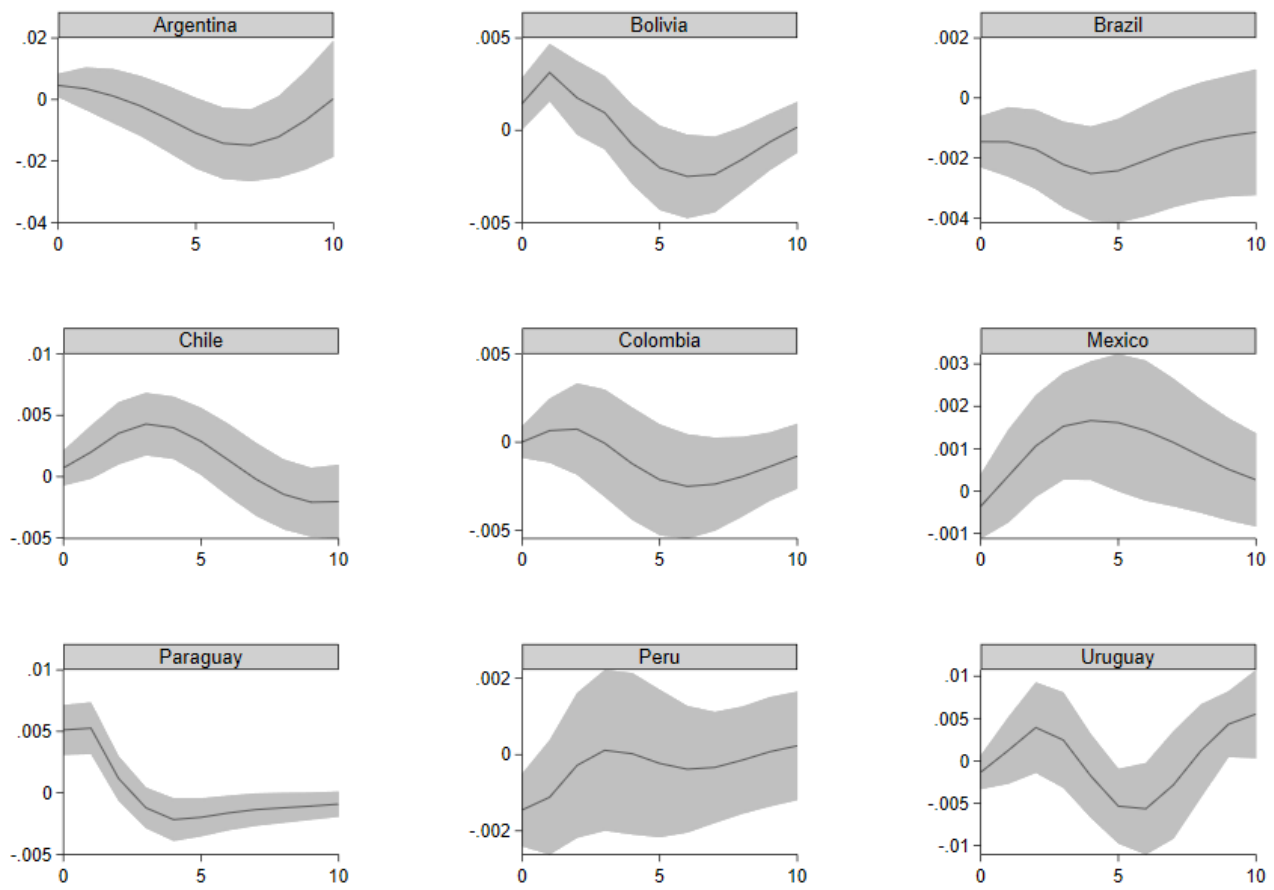

Response of inflation to negative export price shock, SVAR

Figure 2: Response of inflation to negative export price shocks 
Figures 3 and 4 plot the response of nominal exchange rate to positive and negative commodity export price shocks.
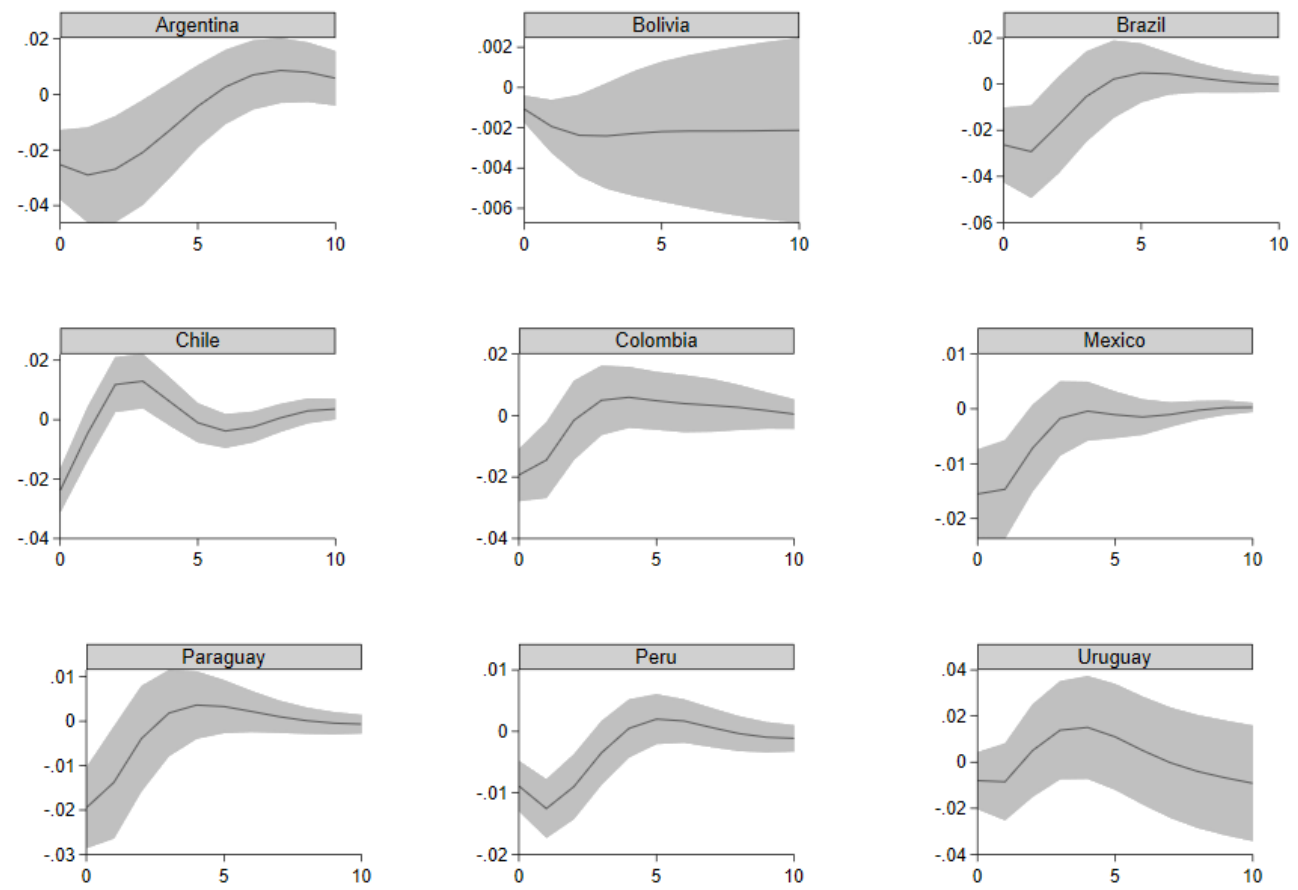

Response of LCU/USD exchange rate to positive export price shock, SVAR

Figure 3: Response of exchange rate to positive export price shocks

Unsurprisingly, positive export price shocks are shown to lead to exchange rate appreciation in all countries in the sample. However, while in most countries the impact appears to have largely dissipated after 8-10 quarters, it seems more persistent for Uruguay. On the other hand, when the export price shock is negative, even though it leads to exchange rate depreciation in the short run, as it does in other countries, the effect turns the opposite direction after about 6 quarters.

Overall, the estimations show that the price responses to commodity export price shocks are asymmetrical in Uruguay. When the export price shock is positive, the responses of inflation and exchange rate are as expected-inflation increases and exchange rate appreciates, leading to real exchange rate appreciation. But when the export price shock is negative, both the responses of inflation and exchange rate appear ambiguous at best. These results are 
consistent with the observed behavior of inflation and real exchange rate in Uruguay during and after the commodity price boom in the 2000s.
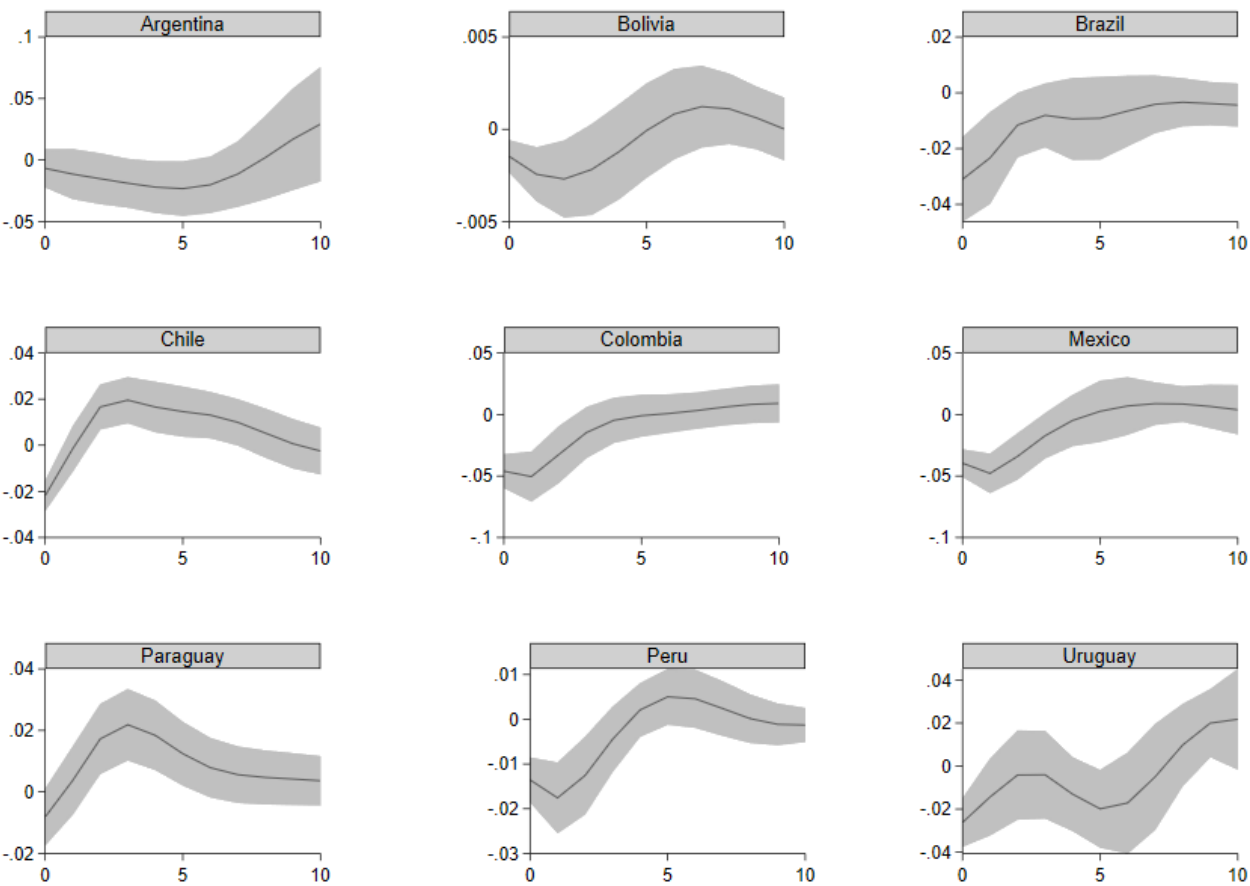

Response of LCU/USD exchange rate to negative export price shock, SVAR

Figure 4: Response of exchange rate to negative export price shocks 


\section{Annex III. Country Groups}

The high-growth peer country group:

\begin{tabular}{|l|r|}
\hline Country & Year \\
\hline Austria & 1953 \\
\hline China, Hong Kong SAR & 1975 \\
\hline Cyprus & 1979 \\
\hline Germany & 1953 \\
\hline Ireland & 1986 \\
\hline Israel & 1955 \\
\hline Japan & 1966 \\
\hline Malaysia & 2005 \\
\hline Malta & 1987 \\
\hline Portugal & 1987 \\
\hline Republic of Korea & 1990 \\
\hline Seychelles & 1984 \\
\hline Singapore & 1979 \\
\hline Spain & 1964 \\
\hline Taiwan & 1985 \\
\hline
\end{tabular}

The trade rival country group:

\begin{tabular}{|l|r|}
\hline Country & \multicolumn{1}{|l|}{ Year } \\
\hline Paraguay & 2017 \\
\hline New Zealand & 2015 \\
\hline Australia & 2015 \\
\hline Suriname & 2014 \\
\hline Guyana & 2017 \\
\hline Argentina & 2017 \\
\hline
\end{tabular}




\section{Annex IV. Structural Indicator Sources}

\begin{tabular}{|c|c|}
\hline Indicator & Source \\
\hline Corruption & International Country Risk Guide \\
\hline Government Stability & International Country Risk Guide \\
\hline Law \& Order & International Country Risk Guide \\
\hline Bureaucracy Quality & International Country Risk Guide \\
\hline Cooperation in Labor-employer Relations & World Economic Forum Global Competitiveness Report \\
\hline Flexibility of Wage Determination & World Economic Forum Global Competitiveness Report \\
\hline Hiring and Firing Practices & World Economic Forum Global Competitiveness Report \\
\hline Redundancy Costs & World Economic Forum Global Competitiveness Report \\
\hline Employees in Workplaces Covered by Unions & World Economic Forum Global Competitiveness Report \\
\hline Hiring Regulations and Minimum Wage & Fraser Institute Economic Freedom of the World \\
\hline Hiring and Firing Regulations & Fraser Institute Economic Freedom of the World \\
\hline Centralized Collective Bargaining & Fraser Institute Economic Freedom of the World \\
\hline Percentage of Secondary Complete & Barro and Lee Educational Attainment Database \\
\hline Years of Schooling & Barro and Lee Educational Attainment Database \\
\hline Percentage of Tertiary Complete & Barro and Lee Educational Attainment Database \\
\hline PISA Mean Performance on the Mathematics Scale & World Bank Education Statistics \\
\hline PISA Mean Performance on the Science Scale & World Bank Education Statistics \\
\hline Quality of the Education System & World Economic Forum Global Competitiveness Report \\
\hline Transport Infrastructure & World Economic Forum Global Competitiveness Report \\
\hline Quality of Overall Infrastructure & World Economic Forum Global Competitiveness Report \\
\hline Domestic Credit to Private Sector ( $\%$ of GDP) & World Bank Global Financial Development Indicators \\
\hline Bank Return on Assets & World Bank Global Financial Development Indicators \\
\hline Getting Credit Score & World Bank Doing Business \\
\hline Integrity of the Legal System & Fraser Institute Economic Freedom of the World \\
\hline Judicial Independence & Fraser Institute Economic Freedom of the World \\
\hline Compliance Costs of Importing and Exporting & World Economic Forum Global Competitiveness Report \\
\hline Profit Tax (\% of profit) & World Bank Doing Business \\
\hline Labor Tax and Contributions (\% of profit) & World Bank Doing Business \\
\hline Other Taxes (\% of profit) & World Bank Doing Business \\
\hline Total Tax and Contribution Rate (\% of profit) & World Bank Doing Business \\
\hline Starting a Business & World Bank Doing Business \\
\hline Business Regulations & World Bank Doing Business \\
\hline Ease of Doing Business Score & World Bank Doing Business \\
\hline Cost to Export (US\$ per container deflated) & World Bank Doing Business \\
\hline Public Debt (as \% of GDP) & IMF World Economic Outlook \\
\hline REER & IMF World Economic Outlook \\
\hline Exchange rate & IMF World Economic Outlook \\
\hline Inflation & IMF World Economic Outlook \\
\hline Population Growth & World Bank World Development Indicators \\
\hline New Business Density & World Bank World Development Indicators \\
\hline
\end{tabular}

